\title{
Late Paleoproterozoic (1900-1800 Ma) nappe stacking and polyphase deformation in the Hengshan-Wutaishan area: Implications for the understanding of the Trans-North-China Belt, North China Craton
}

\author{
P. Trap ${ }^{\text {a, }}$, M. Faure ${ }^{\mathrm{a},}$, W. Lin ${ }^{\mathrm{b},}$ and P. Moniéc, \\ anstitut des Sciences de la Terre d'Orléans, CNRS—Université d'Orléans (UMR 6113), \\ 45067 Orléans Cedex 2, France \\ ${ }^{\mathrm{b}}$ State Key Laboratory of Lithospheric Evolution, Institute of Geology and Geophysics, \\ Chinese Academy of Sciences, Beijing 100029, China \\ ${ }^{c}$ Laboratoire de Dynamique de la Lithosphère UMR CNRS 5573, INSU Université \\ Montpellier II, 34095 Montpellier Cedex 5, France
}

\begin{abstract}
The Hengshan-Wutaishan area forms part of the Trans-North-China Belt developed in response to the final amalgamation of the North China Craton. The Hengshan-Wutaishan domain and the adjacent Fuping massif constitute the largest and the most representative rock exposure of the belt. A structural study allows us to redefine the lithological and tectonic units that compose the architecture of the Hengshan-Wutaishan domain and to propose that the Trans-North-China Belt was built up through a polyphase tectonic evolution within the period 1900-1800 Ma. The first event (D1) corresponds to the emplacement of lower and upper nappes herein called the Orthogneiss and Volcanites Unit (OVU) and the Low Grade Mafic Unit (LGMU), respectively. The OVU mainly consists of rocks formed in an arc system and metamorphosed under amphibolite facies conditions whereas the LGMU represents oceanic crust rocks with an arc component that underwent greenschist facies metamorphism. The synmetamorphic D1 deformation is characterized by a NW-SE stretching and mineral lineation with a top-to-the SE sense of shear that corresponds to the sense of nappe motion. U-Th- $\mathrm{Pb}$ EPM chemical dating on monazite from three metapelites of the OVU gives isochron ages of $1884 \pm 11 \mathrm{Ma}, 1886 \pm 5 \mathrm{Ma}$ and $1887 \pm 4 \mathrm{Ma}$ interpreted as the age of the prograde amphibolite facies metamorphism coeval with nappe stacking during the D1 event. The D2 event corresponds to a widespread crustal melting of the OVU and underlying basement rocks in Hengshan related to the exhumation of deep structures about 20-30 Ma after nappe emplacement. The migmatite contains blocks of retrograded eclogite or HP-granulitic restites, and is characterized by the development of a pervasive foliation and lineation. A late D2 event represents the folding stage of the migmatitic foliation during the completion of a dome. The Orthogneiss and Volcanics Unit and the Low Grade Mafic Unit are unconformably covered by weakly metamorphosed to unmetamorphosed sediments belonging to the Hutuo Supergroup. These rocks were deformed by a ductile D3 event, characterized by a NW-SE trending stretching lineation, south verging folds associated with an axial planar slaty cleavage and an E-W crenulation lineation. Lastly, a left-lateral wrenching along the Zhujiafang Shear Zone separates the northern and southern parts of Hengshan. Our structural
\end{abstract}


study shows that there is no significant difference between the southern part of Hengshan and the lower part of Wutaishan, both areas belong to OVU and show a structural continuity. We suggest that this polyphase deformation developed in response to a north-westward subduction of an old ocean, named the Lüliang Ocean, beneath the Western Block, followed by collision with a micro-continent named the Fuping Block at $\sim 1890-1880 \mathrm{Ma}$.

Keywords: Structural analysis; Polyphase deformation; Crustal melting; Th-U-Pb monazite ages; Trans-North-China Belt; North China Craton

\section{Introduction}

The North China Craton formed by amalgamation of two Archean blocks named the Eastern Block (EB) and the Western Block (WB) along a central highly deformed zone called the Trans-North-China Belt (TNCB) (Zhao et al., 1999a) which forms a $300 \mathrm{~km}$ wide and $1000 \mathrm{~km}$ long north-south trending collisional orogen (Fig. 1A). The Hengshan-WutaishanFuping massifs ([Liu et al., 1985] and [Sun et al., 1992]), located about $350 \mathrm{~km}$ west-southwest of Beijing, represent the best exposed area of the TNCB (Fig. 1B). Because of good outcrops, the structural, petrological, geochronological and geochemical features of the Hengshan-Wutaishan-Fuping area have been intensively studied ([Wilde et al., 1997], [Wilde et al., 1998], [Liu, 1996], [Liu et al., 2002], [Liu et al., 2004], [Wang et al., 2004] and [Zhao et al., 2004] and references therein). Many models have been proposed to explain the tectonic evolution of the Trans-North-China Belt through the studies of the Hengshan-WutaishanFuping area. However, two principal issues remain disputed: (1) the structural relationships between Hengshan, Wutaishan and Fuping massifs; (2) the age of the main metamorphic and structural event related to collision. Consequently, there is still no consensus about general elements of the geodynamic evolution of the Trans-North-China Belt, such as the number of blocks involved or the sense of subduction before collision. According to authors, the collision might have occurred between $2.55 \mathrm{Ga}$ and $2.45 \mathrm{Ga}$ during the Wutai orogeny ([Ma et al., 1987], [Li and Qian, 1994], [Tian et al., 1996], [Wang et al., 1996], [Li et al., 2000a], [Li et al., 2000b], [Zhai et al., 2000], [Kusky and Li, 2003], [Liu et al., 2004], [Polat et al., 2005] and [Polat et al., 2006]) or between $1.9 \mathrm{Ga}$ and $1.8 \mathrm{Ga}$ during the Lüliang orogeny ([Wilde et al., 2002], [Wilde et al., 2004a], [Wilde et al., 2005], [Guo et al., 2005], [Guan et al., 2002], [Zhao et al., 1999a], [Zhao et al., 1999b], [Zhao et al., 2000b], [Zhao et al., 2002], [Zhao et al., 2005], [Kröner et al., 2005a], [Kröner et al., 2005b] and [Kröner et al., 2006]).

A key issue for a better understanding of the Trans-North-China Belt is to clarify the deformation style of the Hengshan-Wutaishan-Fuping domain. Our field survey allows us to recognize several lithological-tectonic units limited by flat lying ductile shear zones. In this contribution we present new structural maps and a cross section, and argue that the Hengshan-Wutaishan domain represents a stack of synmetamorphic nappes. Moreover, in situ chemical U-Th-Pb EPMA dating on monazite within Al-rich metapelites allows us to accurately constrain the age of the main metamorphism coeval with ductile shearing and nappe stacking during the amalgamation of the North China Craton. Together with geochronological data, our structural study suggests that a polyphase deformation of the Hengshan-Wutaishan area took place from $1900 \mathrm{Ma}$ to $1800 \mathrm{Ma}$. 


\section{Lithological and structural units of the Hengshan-Wutaishan area}

It is often assumed that the Hengshan-Wutaishan-Fuping domain represents three distinct lithotectonic components that correspond to different "terranes" (Fig. 1B; [Bai, 1986], [Bai et al., 1992], [Wang et al., 1996], [Polat et al., 2005] and [Polat et al., 2006]), among which Wutaishan is considered to unconformably overlie both the Hengshan and Fuping massif ([Tian et al., 1996] and [Polat et al., 2005]). The Longquanguan Shear Zone, between the Wutaishan and Fuping massifs is well acknowledged as a main tectonic contact (Fig. 1B; [Li and Qian, 1991], [Xu et al., 1995], [Hao et al., 1995], [Pei et al., 2001], [Sun et al., 2004] and [Zhao et al., 2006]). Conversely, the evidence for a similar tectonic contact between Hengshan and Wutaishan is not documented in the literature. On the basis of our field work, we argue that the Hengshan-Wutaishan area is a stack of two synmetamorphic nappes herein called the "Orthogneiss and Volcanites Unit" (OVU) and the "Low Grade Mafic Unit" (LGMU), for the lower and upper ones, respectively. In Wutaishan, both units are unconformably covered by the Hutuo Supergroup. In addition, a fourth lithological unit, named the Hengshan migmatite, is distinguished in the northern part of the study area. This section presents these four litho-structural units and their bulk architecture.

\subsection{The Orthogneiss and Volcanites Unit (OVU)}

The Orthogneiss and Volcanites Unit (OVU) represents more than half of the WutaishanHengshan area. The southern part of Hengshan, south of the Zhujiafang Shear Zone, belongs to the OVU, which is also recognized in the northern, eastern and south-eastern part of Wutaishan (Fig. 1C). The OVU is characterized by volcanic-sedimentary rocks represented by the supracrustal sequences of Hengshan (Li and Qian, 1994) and the main part of the Shizui Subgroup of Wutaishan (Tian, 1991). The dominant lithology is a kilometer-thick formation characterized by a centimeter to meter-scale alternation of light-colored intermediate to felsic volcanics, amphibolite and biotitic gneiss (Fig. 2A). SHRIMP U-Pb zircon ages from these volcanic rocks range from 2529 Ma to $2513 \mathrm{Ma}$ (Wilde et al., 2004a) which represent ages of rock formation.

Other subordinate sedimentary rocks such as Al-rich metapelites, calc-silicates gneiss, tremolite marbles, quartzite, banded iron formation (BIF) and minor ultramafic rocks form the Banyukou and Jingangku formations of the Shizui Subgroup of Wutaishan (Tian, 1991). They are considered to form the base of the Wutaishan greenstone sequence (Tian, 1991). However, an amphibolite from the Banyukou formation gave a SHRIMP U-Pb zircon age of $2510 \mathrm{Ma}$ which is younger than the volcanic rocks, suggesting that the Banyukou formation cannot be the base of the Wutaishan sequence (Cawood et al., 1998). Moreover, we also recognized similar Al-rich metapelites in the Central Hengshan, north of the Yixingzhai orthogneiss, as previously described by Tian (1991). We consider that the rocks of the Banyukou and Jingangku formations represent the top of the OVU, both recognized in the Hengshan and Wutaishan. Geochemical studies of the metavolcanic rocks indicate a calc-alkaline signature (Li and Qian, 1994) interpreted as due to subduction related magmatic arc.

The OVU is intruded by numerous plutonic bodies, namely the Chechang-Betai, Ekou, Lanzhishan, Shifo, Wangjiahui, grey type of the Guangmingshi and the Yixingzhai orthogneisses (Fig. 5 and Fig. 6). All these plutons exclusively crop-out in the Wutaishan massif except the Yixingzhai orthogneiss that is recognized both in the southern part of the 
Hengshan massif and in the northern edge of the Wutaishan massif (Fig. 1, Fig. 5 and Fig. 6). The OVU plutons consist of granite, granodiorite, diorite and tonalite among which most exhibit a calc-alkaline geochemical signature suggesting a magmatic arc setting ([Liu et al., 2002], [Liu et al., 2004] and [Wilde et al., 2002]).

Due to the pervasive gneissic foliation developed in response to syn-metamorphic deformation (see below), the primary relationship between the granites and volcanosedimentary sequence are rarely preserved. The intrusive contacts are commonly sheared and lie parallel to the regional foliation, observed both in intrusions and in their surrounding metasedimentary host rocks. SHRIMP U-Pb zircon protolith ages of the granitoids range from $2565 \mathrm{Ma}$ to $2515 \mathrm{Ma}$ ([Wilde et al., 1997], [Wilde et al., 2004a] and [Wilde et al., 2005]) that are quite similar to those of the OVU volcanic rocks (see above). Therefore these granitoids are coeval with the volcanic rocks and represent synvolcanic granitoid intrusions marking the setting of a magmatic arc around 2.5 Ga ([Wilde et al., 2005] and [Kröner et al., 2005a]). Geochronological evidences show that this arc system could develop upon an older continental basement formed around 2.7 Ga ([Wilde et al., 1998], [Wilde et al., 2002], [Kröner, 2002] and [Kröner et al., 2005a]). Furthermore, a younger generation of granitoids represented by the Shifo monzogranite and the pink facies of the Wangjiahui monzosyenite in Wutaishan (Fig. 6) has an emplacement age of $\sim 2.1-2.0$ Ga ([Wilde et al., 2005] and [Kröner et al., 2005a]). All the above described OVU rocks experienced an amphibolite facies metamorphism with $P-T$ conditions up to $10-12$ kbar and $600-650{ }^{\circ} \mathrm{C}$ (Zhao et al., 1999b). The OVU overthrusts the Fuping massif along the kilometer-scale Longquanguan Ductile Shear Zone.

\subsection{The low grade mafic unit (LGMU)}

The Low Grade Mafic Unit (LGMU) forms the central and highest part of the Wutaishan massif. It corresponds to the Taihuai and Gaofan Subgroups of the lithostratigraphic column of Wutaishan (Tian, 1991). This unit consists mostly in basalts, sometimes with pillow structure (Fig. 2B), intermediate to felsic volcaniclastic rocks, serpentinized ultramafic rocks and minor sandstones, siltstones and BIF ([Bai, 1986] and [Tian, 1991]). Zircon grains from felsic volcanites from the LGMU yield SHRIMP U-Pb ages ranging between $2516 \pm 10 \mathrm{Ma}$ and $2533 \pm 9 \mathrm{Ma}$ (Wilde et al., 2004a). Some volcanic rocks show a calc-alkaline signature (Wilde and Wang, 1995) whereas the MORB like affinity of some basaltic lava is considered as evidence for oceanic crust ([Wang et al., 2004] and [Polat et al., 2005]).

In the Wutaishan, rocks from the LGMU and OVU are considered as a single volcanosedimentary sequence with an increasing metamorphic grade from greenschist to amphibolite facies, from top to bottom (Tian, 1991). Ductile shear zones have been previously observed ([Wu and Zhong, 1998], [Liu et al., 1997], [Liu et al., 2004] and [Cawood et al., 1998]) but not always clearly identified as tectonic boundaries between distinct tectonic and metamorphic units. Moreover, some rocks from the LGMU are older than the underlying rocks of OVU (Cawood et al., 1998). In this paper, we argue that the LGMU is a nappe of greenschist facies volcanic, magmatic and sedimentary rocks that tectonically overlies the OVU through a flat lying ductile shear zone herein named the Upper Wutai Thrust (UWT) where mylonitic fabrics are well developed (see Section 3). 


\subsection{The Hengshan migmatite}

Migmatites are widely developed in Hengshan ([Li and Qian, 1994] and [Yan et al., 1996]), particularly north of the E-W trending Zhujiafang ductile strike slip shear zone. Anatexis is not strictly restricted to the northern part of Hengshan (Fig. 3 and Fig. 5), however it is lacking in Wutaishan. In the Hengshan migmatite, nebulitic structures, ptygmatitic folds and large quartz-feldspar leucocratic domains are in agreement with crustal melting (Fig. 2C). Centimeter to meter sized blocks of mafic granulite and amphibolite are widespread into the migmatites (Fig. 2C and D). These rocks were intensively studied for petrology and geochronology ([Wang et al., 1991], [Li and Qian, 1994], [Li et al., 1997], [Zhao et al., 2001b], [O'brien et al., 2005], [Kröner et al., 2005b], [Kröner et al., 2006] and [Zhang et al., 2006a]). Some mafic granulites could represent intrusive mafic dykes that were buried to HPgranulite or even eclogite facies conditions before their retrogression to amphibolite facies conditions during their exhumation ([Zhao et al., 2001b], [O'brien et al., 2005] and [Kröner et al., 2006]). However field evidence for a dyke setting is absent since the mafic blocks are enclosed within migmatites. When boudin structures are observed, the host rock migmatite is also intensively foliated. The mafic blocks might represent magmatic rocks of the OVU that did not undergo partial melting due to their $\mathrm{Fe}-\mathrm{Mg}$ rich composition and refractory nature. Thus they can be considered as restites and the migmatite does not correspond to the initial host rock of the mafic bodies. The protoliths of the migmatite are sometimes difficult to identify. However in some places, field observation shows that the migmatite developed at the expense of the OVU rocks. Restites of acidic gneiss, amphibolite or metadiorite are sometimes preserved from melting and are pervasively cross-cut by leucocratic melts. Furthermore, the Hengshan migmatite also likely develops at the expense of an older TTG basement (Li and Qian, 1994). Those migmatitic rocks have been previously observed but considered as a part of 2.5 TTG granitoïds ([Li and Qian, 1994], [Tian et al., 1996] and [Li et al., 1997]). In this paper, we distinguish the Hengshan migmatite as a specific unit developed after the main synmetamorphic deformation (D1). Migmatites were deformed during the D2 event related to their emplacement with a domal shape. The age of crustal melting will be discussed in Section 5.

\subsection{The hutuo supergroup}

In the southern part of Wutaishan, both the OVU and LGMU are unconformably covered by weakly to unmetamorphosed sedimentary rocks called the Hutuo Supergroup (Tian, 1991). The lowermost part of the sedimentary sequence consists of conglomerates and pelites, the middle part is dominated by carbonate-rich rocks whereas the uppermost part consists of conglomerate and coarse grain sandstone and siltstone with abundant ripple marks (Fig. 2E). The timing of deposition of such Paleoproterozoic unmetamorphosed sedimentary rocks is very difficult to settle. Presently, a conventional multigrain U-Pb zircon date of 2366 $+103 /-94 \mathrm{Ma}$ is measured in a metabasalt (Wu et al., 1986) and a felsic metatuff yields SHRIMP U/Pb zircon ages of $2087 \pm 9 \mathrm{Ma}$ and $2180 \pm 5 \mathrm{Ma}$ (Wilde et al., 2004b). The significance of these ages for the timing of deposition of the Hutuo Supergroup and the tectonic evolution of the Hengshan-Wutaishan area will be discussed in Section 5.

\subsection{The bulk architecture}

An interpretative kilometer-size structure of the Hengshan-Wutaishan area is drawn in Fig. 3. In the central and SE parts, the stack of syn-metamorphic nappes is unconformably covered by the sedimentary rocks of the Hutuo Supergroup but these rocks are also involved in a SE 
directed ductile shearing (D3, see next section). In the northern area, the deep part of the OVU is reworked by the Hengshan migmatite, which is also foliated and folded (see below). In agreement with Tian (1991), Wutaishan is a succession of antiforms and synforms mainly overturned to the SE. This kilometer-wavelength folding deforms the stack of the LGMU and OVU nappes. The OVU overthrusts to the SE the Fuping massif. Moreover, this interpretation emphasizes the structural continuity between Hengshan and Wutaishan. In particular, the OVU crops out in both massifs.

\section{Polyphase deformation in the Hengshan-Wutaishan domain}

Field and petro-structural analyses allow us to distinguish four deformation events summarized in Fig. 4. A main syn-metamorphic deformation (D1) is reworked by the syn- to late migmatitic D2 event, related to the emplacement the Hengshan migmatite, and by a D3 event that also deforms the Hutuo rocks. Finally a late sinistral strike slip ductile faulting (D4) occurred in Hengshan. These successive events might be related to an evolving stress field. However, the relative structural chronology appears robust making it useful in clarifying the structural evolution of the Hengshan-Wutaishan-Fuping area.

\subsection{The main syn-metamorphic deformation event (D1)}

Most of the Hengshan-Wutaishan area consists of metamorphic rocks with a well defined ENE-WSW striking S1 foliation and a NW-SE trending mineral and stretching L1 lineation that is the most significant microstructure of the study area (Fig. 5 and Fig. 6). S1 and L1 are observed both in the OVU and LGMU. In quartzo-feldspathic rocks, the L1 lineation is defined by elongated quartz ribbons and feldspar aggregates. In gneiss, amphibolites and metapelites of the OVU, the lineation is marked by oriented hornblende, kyanite and biotite aggregates (Fig. 6A). Isoclinal F1 folds with axes parallel to L1 are also developed within the S1 foliation.

In spite of a widespread recrystallization that erased some of the syn-kinematic fabrics, preserved asymmetric structures allow us to infer the D1 kinematics. In rocks from the OVU, shear criteria such as $\sigma$ - or $\delta$-type porphyroclast systems, asymmetrical pressure shadows around garnets and sigmoidal mica fishes, provide a consistent top-to-the SE sense of shear (Fig. 7B and C) coeval with amphibolite facies metamorphism. In the LGMU, the same shear criteria are observed showing also a top-to-the SE shearing suggesting that the two tectonic units were deformed during the same ductile and synmetamorphic D1 event (Fig. 7D). In greenschists from the LGMU, chlorite and muscovite observed in pressure shadows around feldspar porphyroclasts indicates that the S1-L1 fabric developed under greenschist facies metamorphism (Fig. 7E). Consequently, the S1 foliation and L1 lineation develop during tectonic burial, responsible for amphibolite facies and greenschist facies metamorphism, of the OVU and LGMU, respectively.

These L1 and S1 structures are particularly well developed along the two subhorizontal tectonic contacts of the Upper Wutai Thrust (UWT) and Longquanguan Thrust (LQGT) (see below) at the base of the LGMU and OVU nappes, respectively (Fig. 3 and Fig. 6). Along these two main shear zones, the gneissic foliation evolves toward mylonitic and ultramylonitic fabrics (Fig. 7F). 
A ductile shear zone within the Wutaishan lithostratigraphic sequence has been already mapped (Wu and Zhong, 1998) but never considered as an important tectonic contact between two structural units such as the amphibolite facies OVU and the greenschist facies LGMU described above. The shear zone consists of several discrete centimeter-scale mylonitic and ultramylonitic zones that as a whole form a decameter-thick ductile tectonic boundary. Recent models suggest that thrust slices in the Wutaishan moved top-to-the W ([Kröner et al., 2005a] and [Zhao et al., 2004]). In the field, we did not observe such a top-to-the west kinematics. Instead, numerous shear criteria showing top-to-the SE displacement develop along the L1 mineral and stretching lineation within the UWT. Therefore we suggest that the LGMU overthrusts the OVU with a south-eastward direction. Due to later folding and erosion the LGMU occurs as a klippe.

The LQGT, previously called Longquanguan Shear Zone, consists of a $200 \mathrm{~km}$ long and $2 \mathrm{~km}$ thick ductile shear zone that involves both rocks from the Fuping massif and the OVU. Zhao et al. (2004) suggest that the LQG Shear Zone is related to the exhumation of the deep part of the Hengshan-Wutaishan-Fuping domain during the latest stage of the deformation. According to Sun et al. (2004), the LQG Shear Zone was a normal fault before turning into thrust. However, we did not observed relics of extensional structures. In agreement with $\mathrm{Li}$ et al. (2004) we argue that the LQG Shear Zone consists of a major thrust fault and therefore we prefer to use the term "Longquanguan Thrust" (LQGT). Indeed, in agreement with previous studies ([Hao et al., 1995], [Pei et al., 2001] and [Sun et al., 2004]), this tectonic boundary is gently dipping to the NW and contains top-to-the SE kinematics associated with the NW-SE stretching lineation (L1). In particular, some augen orthogneisses, previously named the Longquanguan Augen Gneiss, that are equivalent in age to OVU orthogneisses (Wilde et al., 1997), exhibit an intense ductile deformation with asymmetrical pressure shadows around feldspar porphyroclasts showing a top-the-SE kinematics (Fig. 7B). Furthermore, the flat lying LQGT cross cuts the distinctive structure of the Fuping massif characterized by E-W trending elongated domes and basins. Therefore, we suggest the Fuping massif represents the para-autochtonous domain upon which the OVU is thrust over.

Together with these two main tectonic contacts there are some minor mylonitic shear zones that account for the complexity within each nappe. This is particularly true southeast of Wutaishan, where granitoids from the OVU are tectonically interleaved with LGMU volcanites.

\subsection{The subsolidus and postsolidus D2 deformation in the Hengshan migmatite}

The whole northern part of Hengshan and some minor areas in the southern Hengshan are occupied by migmatite formed by partial melting of TTG basement and rocks from the OVU. Non-oriented primary migmatitic features, coeval with anatexis, are rarely preserved in the Hengshan migmatite. Instead, the migmatite is deformed by a subsolidus to postsolidus event called D2. The D2 deformation is responsible for the development of a penetrative foliation S2 turning these rocks into a gneissic migmatite characterized by a layering marked by flattened leucosomes and melanosomes. North of Zhujiafang Shear Zone, trend and dip of the S2 foliation suggest a domal shape of the migmatite which has frequently a flat lying attitude in the central part of the Northern Hengshan (Fig. 5). Due to recent reactivation and erosion, only the western part of the migmatitic dome crops out. Together with S2, intrafolial F2 folds develop. The amphibolite or granulite restitic blocks are enclosed within the gneissic migmatite (Fig. 8A), other mafic restites suffered brittle stretching resulting in boudinage 
coeval with fluid relocation in the low strain domains (Fig. 8B) (Brown and Rushmer, 1997).

Mineral lineations defined by oriented amphibole are rarely observed but the elongation of restitic blocks defines a N-S direction parallel to the intrafolial F2 fold axis. This L2 lineation could be related to the dome setting. A few kinematic indicators such as asymmetric porphyroblasts suggest a top-to-the north movement during the dome emplacement (Fig. 8C). Some restites that experienced a rigid body rotation are surrounded by asymmetric pressure shadows consistent with a top-to-the north kinematics (Fig. 8A). In north Hengshan, the D1 event is completely erased by the D2 event. In south Hengshan, the distinction between D1 and D2 events is difficult since a late folding turned S1 and S2 parallel (see Section 3.3). Moreover, L1 and L2 are very close in orientation, NW-SE and N-S, respectively. Nevertheless, the deformation observed in the migmatites of the southern Hengshan is related to D2 since migmatization develops after D1.

In Northern Hengshan, the S2 foliation draws a domal shape that is reworked by centimeter to meter scale late D2 folds mainly developed at the dome limbs. The late D2 fold axes are weakly plunging and lie parallel to the strike of S2 resulting in their scattering on the stereogram (Fig. 6). The late D2 folds are characterized by a flat lying axial plane and overturning toward the outer part of the dome. Indeed, the late D2 folds are overturned to the north, west and south in the northern, western and southern parts of the dome, respectively. These cascading folds are characteristic of gneiss domes (Whitney et al., 2004). Therefore, we suggest that the migmatitic domal architecture observed in the North Hengshan is related to buoyancy driven forces rather than anticline upright folding. In this last case, the second-order folds would exhibit vertical or high angle axial plane. In the Huai'n-Datong area, similar domes and recumbent folds have been interpreted to result from a dynamic interplay between vertical (advective) flow and horizontal flattening (Dyrks et al., 1997). As stated above, the eastern part of the dome, East of Zhongzhuang village, is hidden by Cambrian and younger rocks.

\subsection{The post Hutuo deformation event (D3)}

Parts of the above described structures are reworked by meter to decameter-scale, NE-SW to E-W trending, folds (F3) related to another deformation event called D3 that occurs after the deposition of the Hutuo Supergroup (Fig. 4). These F3 folds deform the $\mathrm{S}_{1}$ regional foliation and the NW-SE L1 lineation of the OVU and LGMU, S2 and L2 in South Hengshan, as well as the $S_{0}$ bedding of the sedimentary rocks of the Hutuo Supergroup (Fig. 9). In Wutaishan, particularly in the southern part, the F3 folds are widely south verging. They become upright in the northern edge of the massif and are upright or slightly overturned to the north in the south Hengshan (Fig. 3). F3 folds are associated with an axial planar slaty cleavage S3 and a NE-SW to E-W trending crenulation (Fig. 9D) well developed in the greenschist facies rocks of the LGMU and to a lesser extend in the OVU.

In the lower part of the Hutuo Supergroup, a slaty cleavage develops coevally with F3. Near the fold hinges, the bedding surface $\mathrm{S}_{0}$ is crenulated. The Hutuo unconformity is refolded and even put upside down by this ductile D3 event. Although we never observed any mylonitic fabrics in the Hutuo Supergroup rocks, the lithological discontinuity between the base of the Hutuo Supergroup and the underlying LGMU or OVU foliation is sometimes reworked as a shear surface. Indeed, conglomerates that crop out at the base of the Hutuo Supergroup are deformed. Pebbles exhibit a strong shape fabric with a $\mathrm{N} 150^{\circ}$ to $\mathrm{N} 160^{\circ}$ stretching direction, 
some are just fractured whereas other are ductilely elongated. The stretching direction is parallel to quartz and chlorite fibers, the asymmetry of which indicates a top-to-the SE shearing. Also, the Hutuo Supergroup discontinuity functioned as a reverse fault as it can be seen south of Taihuai where the LGMU overthrusts the Hutuo Supergroup (Fig. 3 and Fig. 6).

A clear distinction can be made between the lower part of the Hutuo Supergroup characterized by a slaty cleavage associated with the D3 event and the upper part of the Hutuo Supergroup where rocks are free of any ductile deformation and show well preserved sedimentary features (Fig. 2E). The transition from the undeformed upper part to the deformed lower part occurs progressively. Therefore, the Hutuo Supergroup represents syn to late orogenic sediments deposited after exhumation of OVU and before or during the D3 deformation event.

\subsection{The late strike-slip shear zones (D4)}

The D4 event is restricted to the Hengshan massif. It is characterized by the development of strike slip shear zones among which the most significant is the kilometer scale Zhujiafang Shear Zone. Near the fault zone, the foliation dips steeply southward before becoming vertical inside the shear zone, an E-W trending mineral lineation largely predominates within the mylonitic and ultramylonitic rocks (Fig. 5). Asymmetric pressure shadows indicate a sinistral sense of shear (Fig. 9E). In southern Hengshan, L4 is observed locally on secondary wrench faults parallel to the Zhujiafang shear zone. The age of the strike slip faults is not constrained yet but it must be younger than D2 since migmatites are deformed by the strike slip shearing.

\subsection{Polyphase deformation and structural levels}

The dome structure of Northern Hengshan is not recognized in Southern Hengshan where the foliation trends broadly E-W as in Wutaishan (Fig. 5 and Fig. 6). It is worth noting that Northern and Southern Hengshan do not represent the same structural levels. Indeed, the former is dominated by migmatite enclosing HP granulites or retrograded eclogites whereas the latter is dominated by OVU rocks and minor migmatite, where only MP granulites are described ([Zhao et al., 2004] and [O'brien et al., 2005]). The mafic restites of the Northern Hengshan represent a structural level $15 \mathrm{~km}$ deeper than those of Southern Hengshan (O'brien et al., 2005). In this consideration, the Zhujiafang Shear Zone may represent a regional structure that probably functioned as a normal ductile fault, responsible for the exhumation of the Northern Hengshan migmatitic dome, before being reworked in a strike slip ductile shear zone. Indeed, in some localities, down dip lineations are mainly observed on the northern edge of the Zhujiafang Shear Zone (Fig. 8F). This provides evidence for an early normal movement of the Zhujiafang Shear Zone related to the D2 event. However, we cannot rule out that this down dip lineation might be an older L1 structure formed during D1.

\section{Timing of nappe stacking}

Our structural study documents the polyphase deformation of the Hengshan-Wutaishan area. In this section we constrain the age of nappe setting related to the main syn-metamorphic deformation event described above as the D1 event that is responsible for the amphibolite facies and greenschist facies metamorphism in the OVU and LGMU, respectively. U-Pb-Th chemical dating was applied to monazite grains from three metapelites W109, W175 and H29 from the Al-rich metasedimentary series of the OVU, known as the Jingangku formation 
(Tian, 1991). Previous petrological studies conclude that rocks from the Jingangku formation experienced an amphibolite facies metamorphism characterized by a clockwise $P-T-t$ path with pressure peak conditions around 10-12 kbar related to burial during collision ([Wang et al., 1997], [Liu et al., 1997], [Zhao et al., 1999b], [Zhao et al., 2000a] and [Zhao et al., 2004]). Several attempts at dating the metamorphism of the Jingangku formation have been made. High grade amphibolites yield a Sm-Nd mineral isochron age of $1851 \pm 9 \mathrm{Ma}$ (Wang et al., 2001). Recently, Liu et al. (2006) suggest that the regional metamorphism in Wutaishan occurred around 1887-1822 Ma using U-Th-Pb EPM dating on monazite.

\subsection{Sample description}

Samples locations are shown in Fig. 3, Fig. 5 and Fig. 6. Sample W109 was taken in the northern edge of Wutaishan, south-east of Ekou village near the temple. It consists of a quartz + garnet + biotite + muscovite + staurolite \pm kyanite micaschist. Sample W175 comes from the northern edge of the Wutaishan, south of Daliniu village, it is a kyanite free gneiss with a main assemblage of biotite + plagioclase + garnet + quartz + staurolite. Sample H29 is from Central Hengshan, south of Zhujiafang village, it is a kyanite-rich gneiss with a main assemblage of biotite + plagioclase + kyanite + garnet \pm staurolite. In agreement with Tian (1991) and Li and Qian (1994), we consider that these three samples belong to the same formation, previously called Jingangku formation, located in the upper part of the OVU.

\subsection{EPMA U-Th-Pb dating on monazite}

Monazite is increasingly used to constrain the timing of metamorphism (e.g. Finger et al., 2002 and reference therein). Indeed, monazite growth is partly controlled by the metamorphic grade. Some studies show that diagenetic monazite can develop in the prehnite-pumpellyite facies ([Rasmussen, 1996] and [Cabella et al., 2001]) but disappear in greenschist facies conditions, where allanite rich epidote is the predominant LREE-bearing mineral (Janots et al., 2006). Metamorphic monazite crystallizes under amphibolite facies conditions, during prograde metamorphism ([Smith and Barreiro, 1990], [Kingsbury et al., 1993], [Bingen et al., 1996], [Simpson et al., 2000], [Foster et al., 2002] and [Fitzsimons et al., 2005]). In addition, monazite grows in magmatic and migmatitic events (Be Mezème et al., 2006).

Monazite is an extremely suitable mineral for non-isotopic dating such as chemical $\mathrm{U}-\mathrm{Th}-\mathrm{Pb}$ dating since the common lead content is very low ([Parrish, 1990] and [Montel et al., 1996]). Moreover, in old-monazite grains, the common lead content becomes negligible with respect to radiogenic lead. In addition, no diffusion of radiogenic lead occurs ([Smith and Barreiro, 1990], [Kingsbury et al., 1993], [Zhu et al., 1997], [Cocherie et al., 1998], [Cocherie et al., 2005], [Simpson et al., 2000] and [Foster et al., 2002]), except if a HT thermal event takes place after the monazite crystallization and during a period longer than $5 \mathrm{Ma}$ ([Smith and Giletti, 1997] and [Suzuki et al., 1994]).

\subsection{Analytical method}

Monazite grains were analyzed in situ directly in the thin section. The internal structure of monazite and textural relationship between monazites and the principal minerals of the assemblage were investigated using BSE images. Electron microprobe measurements were carried out using a Cameca SX50 electron microprobe cooperated by the BRGM and ISTO in Orléans, France. A $20.0 \mathrm{kV}$ accelerating voltage and $100 \mathrm{nA}$ current were used with an electron beam size of $2 \mu \mathrm{m}$. The very small size of the beam allows us to realize transects 
through the monazite grain in order to see chemical zonation. Thus, in addition to $\mathrm{U}$, Th and $\mathrm{Pb}$ used for age calculation, the others elements constitutive of monazite $(\mathrm{P}, \mathrm{Ca}, \mathrm{Si}, \mathrm{Ce}, \mathrm{Y}$, $\mathrm{Nd}, \mathrm{Gd}, \mathrm{La}, \mathrm{Sm}$ and Pr) were also analyzed. Detection limit $(2 \sigma)$ is $150 \mathrm{ppm}$ for $\mathrm{U}$, Th and $\mathrm{Pb}$, the absolute error being taken as $150 \mathrm{ppm}$. For the detailed analytical procedure see Cocherie et al. (1998). U-Th-Pb age calculation was achieved using the EPMA dating software (Pommier et al., 2002) and following the method of Cocherie and Albarede (2001).

\subsection{Dating results}

\subsubsection{Northern Wutaishan metapelite: sample W109}

Fourteen monazite grains were investigated ranging in size from $10 \mu \mathrm{m}$ to $80 \mu \mathrm{m}$. Monazite grains occur as inclusions within mica and quartz of the matrix as well as in garnet rims (Fig. 10A), but not in the garnet core. The BSE image showed no zoning (Fig. 10B). The Th/U values vary widely at $6.4 \pm 5.1$ (S.D.) (Table 1). Consequently the data spread widely in the $\mathrm{Th} / \mathrm{Pb}$ versus $\mathrm{U} / \mathrm{Pb}$ diagram (Fig. 11A). The calculated MSWD of 0.8 makes the 131 data points statically in agreement with a single age. Moreover, the intercept ages (U-Pb age 1874 $+28 /-29 \mathrm{Ma}$ and $\mathrm{Th} / \mathrm{Pb}$ age $1898+25 /-24 \mathrm{Ma}$ ) are within error and the regression line is close to the theoretical isochron. A mean age of $1887 \pm 4$ Ma was calculated at the centroid of the population (Fig. 11A).

\subsubsection{Northern Wutaishan metapelite: sample W175}

Seven monazite grains were used for age calculation (Table 1). All grains are included in biotite except one in quartz. Crystal sizes range from $30 \mu \mathrm{m}$ to $120 \mu \mathrm{m}$ and BSE images do not show any zoning. The variation in $\mathrm{Th} / \mathrm{U}$ values $(5.9 \pm 1.9 \mathrm{~S}$.D.) is less significative than for the previous sample. Consequently, data spreading on the $\mathrm{Th} / \mathrm{Pb}$ versus $\mathrm{U} / \mathrm{Pb}$ diagram is less important and induces a greater error on intercept ages: $\mathrm{Th} / \mathrm{Pb}$ age $1897+50 /-48 \mathrm{Ma}$ and $\mathrm{U} / \mathrm{Pb} 1872+59 /-63 \mathrm{Ma}$ (Fig. 11B). The calculated MSWD of 1.05 makes the 141 data points statically in agreement with a single age. Indeed, the regression line is almost parallel to the theoretical isochron and yields an age of $1886 \pm 5 \mathrm{Ma}$, calculated at the centroid of the data population (Fig. 11B).

\subsubsection{Southern Hengshan metapelite: sample H29}

Six monazite grains were investigated with sizes ranging from $40 \mu \mathrm{m}$ to $80 \mu \mathrm{m}$. Monazite grains occur as inclusion in biotite or along the boundary between biotite and quartz grains. As for the two previous samples, monazite appears without zoning on BSE images. Analytical data are summarized in Table 1 . Th content varies significantly leading to variation in $T h / U$ ratio at $6.1 \pm 3.4$ (S.D.). Consequently, in the $\mathrm{Th} / \mathrm{Pb}$ versus $\mathrm{U} / \mathrm{Pb}$ diagram the data spread widely (Fig. 11C). The regression line is almost parallel to the theoretical isochron and two $\mathrm{U}-\mathrm{Pb}$ and $\mathrm{Th}-\mathrm{Pb}$ intercept ages of $1869+51 /-54 \mathrm{Ma}$ and $1894+43 /-41 \mathrm{Ma}$, respectively, are similar within errors (Fig. 11C). A mean age has been calculated at $1884 \pm 11 \mathrm{Ma}$ at the centroid of the population $(n=110)$.

\subsection{Age significance}

Many studies revealed that monazite growth in metapelites, of intermediate $\mathrm{Fe}-\mathrm{Mg}$ composition (Fitzsimons et al., 2005), under amphibolite facies conditions, is linked directly to breakdown of garnet to produce staurolite ([Spear and Pyle, 2002], [Khon and Malloy, 
2004] and [Fitzsimons et al., 2005]). This is commonly emphasized by petrographical evidence showing that monazite is spatially associated with garnet breakdown and staurolitein reaction (Khon and Malloy, 2004). Similarly to some of these studies ([Spear and Pyle, 2002] and [Khon and Malloy, 2004]), the sample W109 presents garnet overgrowth over monazite produced by earlier garnet breakdown, during prograde metamorphism under amphibolite facies conditions. Therefore, we argue that the concordant $\mathrm{U}-\mathrm{Th}-\mathrm{Pb}$ monazite ages ranging from $1887 \pm 4 \mathrm{Ma}, 1886 \pm 5 \mathrm{Ma}$ and $1884 \pm 11 \mathrm{Ma}$ from the three metapelites W109, W175 and H29 correspond to the age of the prograde amphibolite facies metamorphism coeval with nappe stacking. Theses ages comply with the SHRIMP U-Pb age of metamorphic zircons of $1881 \pm 8 \mathrm{Ma}$ and the mean evaporation ${ }^{207} \mathrm{~Pb} /{ }^{206} \mathrm{~Pb}$ age of $1881.3 \pm 0.4 \mathrm{Ma}$ reported in the Hengshan gneisses ([Kröner et al., 2005a] and [Kröner et al., 2006]). The above presented results agree with a chemical $\mathrm{U}-\mathrm{Th}-\mathrm{Pb}$ monazite age from a kyanite bearing metapelite from southern Hengshan at $1883 \pm 11 \mathrm{Ma}$ (Faure et al., in press).

\section{Discussion}

\subsection{Tectonic significance of the Henghsan-Wutaishan domain and the Fuping massif}

In the literature, two main tectonic models are put forward to account for the geological features of the Hensghan-Wutaishan-Fuping area. In the first one, the Hengshan and Fuping massifs represent two different continental blocks that were welded together by the closure of an oceanic domain ([Kusky and Li, 2003], [Polat et al., 2005] and [Polat et al., 2006]). This intervening ocean is presently preserved in the Wutaishan massif. The bulk structure and metamorphism are related to a northwest directed intraoceanic subduction followed by the collision between the Hengshan and Fuping massifs.

The second model suggests that the Hengshan and Fuping massifs represent the same plutonic part of a Neoarchean-Early Paleoproterozoic ( 2.5 Ga) magmatic arc developed upon the western margin of a continental Eastern Block. The Wutaishan massif is considered as the upper volcanic and sedimentary part of the same arc ([Zhao et al., 2001a], [Wilde et al., 2002] and [Kröner et al., 2005a]). In this model, the Hengshan-Wutaishan-Fuping arc system is deformed and metamorphosed during continent-arc-continent collision due to an eastward subduction of a Neoarchean ocean. Moreover, Zhao et al. (2004) proposed that a back-arc basin floored by oceanic crust developed between the Hengshan-Wutaishan island arc and the Fuping massif, the closure of which would be accommodated by the Longquanguan Thrust.

Our structural and metamorphic study suggests that the Hengshan and Wutaishan have to be considered as a stack of two synmetamorphic nappes, namely the OVU and LGMU, overthrust upon the Fuping massif. Since the same structural, metamorphic and geochronological features are recognized both in the southern part of Hengshan and the lower part of Wutaishan, the reality of a major tectonic boundary between these two massifs appears unlikely. Therefore, we group these two areas within the OVU nappe that is thrust to the southeast upon the Fuping massif along the Longquanguan Thrust during the D1 event.

In agreement with previous studies ([Wilde et al., 1998], [Wilde et al., 2002], [Kröner, 2002] and [Kröner et al., 2005a]), we propose that the magmatic arc, characterized by $\sim 2.5 \mathrm{Ga}$ magmatism and volcanism, developed upon an older continental basement named here the Fuping Block. It is worth noting that the Fuping Block is not limited to the Fuping massif, but 
the TTG basement that underlies the OVU which is sometimes found as restite in the Hengshan migmatite belongs also to the Fuping Block. During collision at 1890-1880 Ma, the Hengshan-Wutaishan arc deformed as several synmetamorphic nappes displaced southeastward. The Fuping massif shows a different and older structure from what we observed in the Hengshan-Wutaishan area ([Liu et al., 2002] and [Faure et al., in press]). We suggest that the Fuping massif represents the foreland upon which nappes thrust over. Furthermore, since evidence for ophiolites is lacking along the Longquanguan Thrust, we suggest that this major tectonic contact represents an intracontinental flat lying ductile shear zone rather than an ophiolitic suture zone (Zhao et al., 2004).

The NE-SW trending L1 mineral and stretching lineation characterized by a top-to-the-SE sense of shear, coeval with a prograde metamorphism, is the most significant structure of the OVU and LGMU nappes. This south-eastward directed movement suggests that the suture zone, where nappes are rooted, is situated more to the NW of Hengshan massif ([Kröner et al., 2005a] and [Zhao et al., 2004]; this study) and not in the Wutaishan massif (Polat et al., 2005). This complies well with the metamorphic polarities of the TNCB where HP units are observed in the northern Hengshan and more to the north in the Datong-Huai' an area (Guo et al., 2005). However, a controversy remains about the sense of the subduction responsible for the $1880 \mathrm{Ma}$ orogeny. Zhang et al. (2006b) propose a south-east ward subduction responsible for the formation of the magmatic arc at $2.5 \mathrm{Ga}$ and subsequent collision at $1.85 \mathrm{Ga}$. These authors interpret the top-to-the SE shearing observed in Wutaishan and the adjacent Fuping complex as "hinterland thrusts". On the contrary, and in agreement with Polat et al. (2005), we suggest that the southeastern part of the TNCB represents a foreland thrust belt. This is confirmed by the presence of the molassic Hutuo Supergroup sediments interpreted as foreland basins ([Polat et al., 2005] and [Polat et al., 2006], this study). Therefore considering the structural and metamorphic polarities of the belt, we suggest that the subduction of the continental blocks involved in the Trans-North-China collision may not be south-eastward ([Kröner et al., 2005a] and [Zhao et al., 2005]) but more likely north-westward ([Hao et al., 1995], [Kusky and Li, 2003], [Polat et al., 2005] and [Faure et al., in press]). In our model, the suture zone that we called the Trans-North-China Suture (Faure et al., in press) results from the north-westward subduction of an oceanic lithosphere followed by the continental subduction of the Fuping Block below the Western Block. In reference to the Lüliang orogeny of the Chinese literature (e.g. Ma and $\mathrm{Wu}, 1981$ ), we named this oceanic domain, lying between the Western and Fuping Blocks, the Lüliang Ocean. The LGMU, which overlies the arc derived OVU, represents remnant parts of the Lüliang Ocean. The north-westward continental subduction of the Fuping Block was responsible for the metamorphism coeval with the nappe stacking observed in the Hengshan-Wutaishan area. The widespread migmatization of the northern Hengshan developed, after thrusting, during the exhumation of the deeply buried and high grade metamorphosed part of the OVU and the TTG basement of the Fuping Block.

\subsection{Timing of the tectonic-metamorphic evolution}

Numerous radiometric datings have been performed in the Hengshan-Wutaishan domain but as for the tectonic evolution discussed in the previous section, two schools of thought disagree on the time of collision and final amalgamation of the NCC. For some authors, it occurred in Neoarchean-Early Paleoproterozic, around 2.5 Ga ([Kusky and Li, 2003], [Polat et al., 2005] and [Polat et al., 2006]), and for others it took place in Late Paleoproterozoic around $1.85 \mathrm{Ga}$ (e.g. [Zhao et al., 2005] and [Kröner et al., 2006]). In agreement with the latter authors, we 
argue that the $2.5 \mathrm{Ga}$ ages are protolith ages that represent the magmatic setting of the OVU rocks during the formation of the arc, and do not indicate the age of the collision.

Radiometric ages of the tectono-metamorphic events remain rare. Recent SHRIMP U-Pb zircons ages of the OVU granitoids and high-pressure granulites from Hengshan suggest that metamorphism took place between $1880 \mathrm{Ma}$ and $1850 \mathrm{Ma}$ in response to collision ([Wilde et al., 2002], [Kröner et al., 2005a], [Kröner et al., 2005b] and [Kröner et al., 2006]). Although we agree that the Trans-North-China Belt developed in Late Paleoproterozoic times rather than in the Neoarchean, our study allows us to propose a more accurate timing of the geological events that took place in the period ranging from $1900 \mathrm{Ma}$ to $1800 \mathrm{Ma}$.

In this study, the chemical $\mathrm{U}-\mathrm{Th}-\mathrm{Pb}$ monazite ages of the HP metapelites, that did not present evidence of crustal melting, indicate that prograde metamorphism related to nappe sacking ((D1) event) occurred around 1890-1880 Ma. Thus, we suggest nappe stacking may occur around 1890-1880 Ma.

In Hengshan, SHRIMP and evaporation U-Pb zircon ages from HP granulites blocks enclosed in migmatites range around 1860-1850 Ma ([Chang et al., 1999], [Kröner et al., 2005a], [Kröner et al., 2005b] and [Kröner et al., 2006]). The authors consider that these dates represent the time of peak metamorphism. We suggest that they correspond in fact to the time of metamorphic temperature peak but probably not the metamorphic pressure peak. Indeed, zircons from a migmatitic leucosome sampled in northern Hengshan yield LA-ICPMS U-Pb ages of $2686 \pm 7 \mathrm{Ma}$ and $1850 \pm 10 \mathrm{Ma}$, from cores and rims ([Trap et al., 2006] and [Faure et al., in press]). The former date is interpreted as the age of inherited zircon whereas the latter one represents the age of crystallization of anatexis melt. Therefore, the $1860-1850 \mathrm{Ma} \mathrm{U}-\mathrm{Pb}$ zircon ages probably correspond to the high thermal regime associated to crustal melting characterized by temperature up to $850-900{ }^{\circ} \mathrm{C}$ ([Zhao et al., 2001b] and [O'brien et al., 2005]). These preliminary results suggest that in the TNCB, anatexis occurred about 20-30 Ma after tectonic burial. Such a lag between tectonic thickening and exhumation has been previously observed in some Phanerozoic orogens such as the Aegean or the Variscan Belts ([Buick and Holland, 1989] and [Faure et al., 2005]). Nevertheless, more radiometric dating of leucosomes has to be achieved in order to assess the time of migmatization.

Authors who propose that collision occurred during the Late Paleoproterozoic Lüliang movement $(\sim 1.8-1.9 \mathrm{Ga})$ consider that the Hutuo Supergroup is a precollisional formation (e.g. Wilde et al., 2004b). However, the Hutuo Supergroup rocks are mostly terrigeneous and are considered to represent molasse-type sediments derived from the erosion of the inner part of the TNCB (Tian, 1991). Furthermore, the weakly to unmetamorphosed rocks from the Hutuo Supergroup unconformably overlie the greenschist facies LGMU and amphibolite facies OVU rocks (Fig. 1, Fig. 3 and Fig. 4). Thus the Hutuo Supergroup rocks were deposited after the exhumation of rocks formed at depth during the D1 event. Wilde et al. (2004b) dated tuffs from the Hutuo Supergroup using the SHRIMP U/Pb zircon technique and produced ages of $2087 \pm 9 \mathrm{Ma}$ and $2180 \pm 5 \mathrm{Ma}$. These are not in agreement with the above discussed radiometric ages for D1 and D2 events. Moreover, the lithology of the dated felsic metatuff considered as belonging to the Hutuo Supergroup does not comply well with the clastic nature of molassic sediments. Thus the possibilities that the dated zircons are inherited grains or that the metatuffs do not belong to the Hutuo Supergroup should be considered. On the basis of our structural study, we suggest here, that the Hutuo Supergroup deposited after the exhumation of the metamorphic core of the TNCB, i.e. after ca. $1850 \mathrm{Ma}$. 
In support of the Hutuo Supergroup sedimentary rocks being syn-orogenic is the observation that they are ductilely deformed through the D3 event during or after their deposition. The

absolute timing of the D3 event is not well constrained, however, it must occur before $1770 \mathrm{Ma}$, age of the unmetamorphosed mafic dyke swarm that cross cut the TNCB (Halls et al., 2000).

\subsection{Issues of the timing gap between $2.5 \mathrm{Ga}$ and $1.8 \mathrm{Ga}$}

It is worth noting that the above scenario involving north-westward subduction, collision between the Western Block and the Fuping Block and crustal melting (exhumation of HP granulite) is only valid for the period 1900-1800 Ma. Indeed, the involved continental blocks were already formed during the $2.7-2.5$ Ga period that corresponds to the main crustal growth phase (Wu et al., 2005).

In some models ([Zhao et al., 2004] and [Kröner et al., 2005a]), only one subduction zone located NW of Hengshan, is responsible for both the development of the 2.5 Ga magmatic arc and its subsequent deformation and metamorphism during collision at $\sim 1850 \mathrm{Ma}$. As suggested by several authors (e.g. [Wilde et al., 2002] and [Kusky and Li, 2003]), such a long lived subduction ( $>600 \mathrm{Ma}$ ) remains problematic, especially for an orogen formed during the Archean to Paleoproterozoic time when plate motion should be faster than in the Phanerozoic time ([Hamilton, 1998] and [Marshak, 1999]). Nevertherless, a long lived subduction is also put forward in some Precambrian orogen (e.g. [Karlstrom et al., 2001] and [Corrigan et al., 2000]).

However, the abundance of 2.1 Ga granitoids in the Hengshan-Wutaishan and Fuping area ([Wilde et al., 2005], [Kröner et al., 2005a] and [Zhao et al., 2002]) indicates that an important magmatic event took place at that time. In agreement with Liu et al. (2002), we suggest that the 2.1 magmatism is related to a tectonic event. In contrast to the $2.5 \mathrm{Ga}$ arc magmatism, the $2.1 \mathrm{Ga}$ event occurred only $200 \mathrm{Ma}$ before the Trans-North-China tectonics and thus is more plausibly related to a tectonic event that preceded the TNCB collision.

Our model suggests a north-westward subduction between the Western Block and the Fuping Block. Such a north-westward subduction cannot account for formation of the $2.5 \mathrm{Ga}$ magmatic arc situated more to the east of the subduction zone. Therefore, we suggest that a second subduction has to be considered. In this view, the $2.5 \mathrm{Ga}$ arc magmatism should be due to a west directed subduction located east of the Fuping massif. This westward subduction could also be responsible for the $2.1 \mathrm{Ga}$ tectonothermal event. However, in the present state of knowledge a satisfactorily Neoarchean-Early Paleoproterozoic geodynamic scenario remains highly speculative.

\section{Conclusion}

The structural and geochronological data presented in the previous sections allow us to propose a new tectonic setting for the Hengshan-Wutaishan domain within the Trans-NorthChina Belt. In Neoarchean, ca. $2.5 \mathrm{Ga}$, a magmatic arc developed upon the continental Fuping Block and the Lüliang Ocean separated this arc from a Western Block located more to the northwest. In Late Paleoproterozoic, the north-westward subduction of the Lüliang Ocean below the Western Block is responsible for the subsequent collision with the Fuping Block at 1890-1880 Ma. Exhumation of the highly metamorphosed continental crust occurred at 
1860-1850 Ma and was coeval with the development of migmatites. The exhumation of the metamorphic rocks was followed by a new ductile event during or after the deposit of the terrigeneous sedimentary rocks of the Hutuo Supergroup. An undeformed mafic dyke swarm marked the end of the orogeny at $\sim 1770 \mathrm{Ma}$. The geodynamic setting of the $2.5 \mathrm{Ga}$ magmatic arc and the 2.1 Ga magmatism remains unsettled.

\section{Acknowledgements}

The field work for this research was financially supported by a National Science Foundation of China grant $n^{\circ} 40472116$. The monazite analyses were carried out on the Cameca SX 50 Electronic Microprobe operated by a consortium consisting of the Institut des Sciences de la Terre d'Orléans, the Bureau de Recherche Géologique et Minière and the University of Orléans, France. Alain Cocherie is thanked for approving the EPMA results. We appreciate the assistance of Olivier Rouer and Christian Gilles during EPM analysis and data reduction.

Guochun Zhao and Allan Collins are thanked for constructive and useful reviews.

\section{References}

Bai, 1986 J. Bai, The Precambrian crustal evolution of the Wutaishan area. In: J. Bai, Editor, The Early Precambrian Geology of Wutaishan, Tianjin Science and Technology Press, Tianjin (1986), pp. 376-383 (in Chinese).

Bai et al., 1992 J. Bai, R.Z. Wang and J.J. Guo, The Major Geologic Events of Early Precambrian and Their Dating in Wutaishan Region, Geological Publishing House, Beijing (1992).

Be Mezème et al., 2006 E. Be Mezème, A. Cocherie, M. Faure, O. Legendre and Ph. Rossi, Electron microprobe monazite geochronology of magmatic events: examples from Variscan migmatites and granitoids, massif central, France, Lithos 87 (2006), pp. 276-288.

Bingen et al., 1996 B. Bingen, D. Demaiffe and J. Hertogen, Redistribution of rare earth elements, thorium, and uranium over accessory minerals in the course of amphibolite to granulite facies metamorphism: the role of apatite and monazite in orthogneisses from southwestern Norway, Geochim Cosmochim Acta 60 (1996), pp. 1341-1354.

Brown and Rushmer, 1997 M. Brown and T. Rushmer, The role of deformation in the movement of granitic melt: views from the laboratory and the field. In: M.B. Holmes, Editor, Deformation-Enhanced Fluid Transport in the Earth Crust and mantle. The Mineralogical Society Series 8, Chapman \& Hall (1997), pp. 111-144.

Buick and Holland, 1989 I.S. Buick and T.J.B. Holland, The $P-T-t$ path associated with crustal extension, Naxos, Cyclades, Greece. In: J.S. Daly, Editor, Evolution of Metamorphic Belts, Geological Society of Special Publication (1989), pp. 365-369. 
Cabella et al., 2001 R. Cabella, G. Lucchetti and P. Marescotti, Authigenic monazite and xenotime from pelitic metacherts in pumpellyite-actinolite facies conditions, Sestri-Voltaggio zone, Central Liguria, Italy, Can. Mineral. 39 (2001), pp. 717-727.

Cawood et al., 1998 P. Cawood, S.A. Wilde, K.Y. Wang and A. Nemchin, Integrated geochronology and field constraints on subdivision of the Precambrian in China: data from the Wutaishan, Abstract of the 9th International Conference on Geochronology, Cosmochronology and Isotope Geology, Beijing, Chinese Sci. Bull. 43 (1998), p. 17.

Chang et al., 1999 X.Y. Chang, Y.D. Chen and B.Q. Zhu, U-Pb zircon isotope age of metabasites from Hengshan grey gneiss, Acta Mineral. Sin. 19 (1999), pp. 263-266 (in Chinese with English abstract).

Cocherie and Albarede, 2001 A. Cocherie and F. Albarede, An improved U-Th-Pb age calculation for electron microprobe dating of monazite, Geochim. Cosmochim. Acta 65 (2001), pp. 4509-4522.

Cocherie et al., 2005 A. Cocherie, E. Be Mezeme, O. Legendre, M.C. Fanning, M. Faure and $\mathrm{P}$. Rossi, Electron microprobe dating as a tool for determining the closure of $\mathrm{Th}-\mathrm{U}-\mathrm{Pb}$ systems in migmatitic monazites, Am. Mineral. 90 (2005), pp. 607-618.

Cocherie et al., 1998 A. Cocherie, O. Legendre and J.J. Peucat, Geochronology of polygenetic monazites constrained by in situ electron microprobe Th-U-total lead determination: implications for lead behaviour in monazite, Geochim. Cosmochim. Acta 62 (1998), pp. 24752497.

Corrigan et al., 2000 D. Corrigan, T. Rivers and G. Dunning, U-Pb constraints for the plutonic and tectonometamorphic evolution of Lake Melville terrane, Labrador and implications for basement reworking in the northeastern Grenville Province, Precambrian Res. 99 (2000), pp. 65-90

Faure et al., 2005 Faure, M., Be Mézème, E., Duguet, M., Cartier, C., Talbot, J.-Y., 2005. Paleozoic tectonic evolution of medio-Europa from the example of the French Massif Central and Massif Armoricain. In: Carosi, R., Dias, R., Iacopini, D., Rosenbaum, G. (Eds.), The southern Variscan belt, Journal of the Virtual Explorer 19, Paper 5.

Faure, M., Trap, P., Lin, W., Monié, P., Bruguier, O., in press. The formation of the North China Craton by two Paleoproterozoic continental collisions in Lüliang-HengshanWutaishan-Fuping massifs. Episodes.

Finger et al., 2002 F. Finger, E. Krenn, G. Riegler, S. Romano and G. Zulauf, Resolving Cambrian, Carboniferous, Permian and Alpine monazite generations in the polymetamorphic basement of eastern Crete (Greece) by means of the electron microprobe, Terra Nova 14 (2002), pp. 233-240.

Fitzsimons et al., 2005 I.C.W. Fitzsimons, P.D. Kinny, S. Wetherley and D.A. Hollingsworth, Bulk chemical control on metamorphic monazite growth in pelitic schists and implications for U-Pb age data, J. Metamorph. Geol. 23 (2005), pp. 261-277 
Foster et al., 2002 G. Foster, H.D. Gibson, R. Parrish, M. Horstwood, J. Fraser and A. Tindle, Textural, chemical and isotopic insights into the nature and behaviour of metamorphic monazite, Chem. Geol. 191 (2002), pp. 183-207.

Guan et al., 2002 H. Guan, M. Sun, S.A. Wilde, X.H. Zhou and M.G. Zhai, SHRIMP U-Pb zircon geochronology of the Fuping Complex: implications for formation and assembly of the North China craton, Precambrian Res. 113 (2002), pp. 1-18.

Guo et al., 2005 J.H. Guo, M. Sun, F.K. Chen and M.G. Zhai, Sm-Nd and SHRIMP U-Pb zircon geochronology of high-pressure granulites in the Sanggan area North China Craton: timing of Paleoproterozoic continental collision, J. Asian Earth Sci. 24 (2005), pp. 629-642.

Halls et al., 2000 H.C. Halls, J.H. Li, D. Davis, G.T. Hou, B.X. Zhang and X.L. Qian, A precisely dated Proterozoic palaeomagnetic pole from the North China Craton, and its relevance to palaeocontinental reconstruction, Geophys. J. Int. 143 (2000), pp. 185-203.

Hamilton, 1998 W.B. Hamilton, Archean magmatism and deformation were not products, Precambrian Res. 91 (1998), pp. 143-179.

Hao et al., 1995 J. Hao, K.Y. Wang and S.P. Zhou, Discussion on stratigraphic and tectonic features of "Longquanguan Group" in the south west piedmont of Wutai mountain and relevant problems, Sci. Geol. Sin. 30 (1995), pp. 183-189 (in Chinese with English abstract).

Janots et al., 2006 E. Janots, F. Negro, F. Brunet, B. Goffé, M. Engi and M.L. Bouybaouène, Evolution of the REE mineralogy in HP-LT metapelites of the Sebtide complex, Rif, Morocco: monazite stability and geochronology, Lithos 87 (2006), pp. 214-234.

Karlstrom et al., 2001 K.E. Karlstrom, K.I. Ahäll, S.S. Harlan, M.L. Williams, J.M. Lelland and J.W. Geissman, Long-lived (1.8-1.0 Ga) convergent orogen in southern Laurentia, its extensions to Australia and Baltica, and implications for refining Rodinia, Precambrian Res. 111 (2001), pp. 5-30.

Kingsbury et al., 1993 J.A. Kingsbury, C.F. Miller, J..L. Wooden and T.M. Harrison, Monazite paragenesis and $\mathrm{U}-\mathrm{Pb}$ systematics in rocks of the eastern Mojave Desert, CA, USA: implications for thermochronometry, Chem. Geol. 110 (1993), pp. 147-167.

Kröner, 2002 A. Kröner, Zircon ages of the Hengshan Complex. In: A. Kröner, G.C. Zhao, S.A. Wilde, M.G. Zhai, C.W. Passchier, M. Sun, J.H. Guo, P.J. O’Brien and N. Walte, Editors, A late Archean to Paleoproterozoic Lower to Upper Crustal Section in the Hengshan-Wutaishan Area of the North China. Guidebook for Penrose Conference Field Trip, Chinese Academy of Sciences, Beijing (2002), pp. 28-32.

Kröner et al., 2005a A. Kröner, S.A. Wilde, J.H. Li and K.Y. Wang, Age and evolution of a late Archean to early Palaeoproterozoic upper to lower crustal section in the Wutaishan/Hengshan/ Fuping terrain of northern China, J. Asian Earth Sci. 24 (2005), pp. $577-596$.

Kröner et al., 2005b A. Kröner, J.H. Li, S.A. Wilde, P.J. O’Brien, N.P. Walte and C.P. Passchier, Zircon ages and evolution of a late Archean to Paleoproterozoic lower crustal section in the Hengshan terrain of northern China, Acta Geol. Sin. 79 (2005), pp. 605-629. 
Kröner et al., 2006 A. Kröner, S.A. Wilde, G.C. Zhao, P.J. O’Brien, M. Sun, D.Y. Liu, Y.S. Wan, S.W. Liu and J.H. Guo, Zircon geochronology and metamorphic evolution of mafic dykes in the Hengshan Complex of northern China: evidence for late Palaeoproterozoic extension and subsequent high-pressure metamorphism in the North China Craton, Precambrian Res. 146 (2006), pp. 45-67

Khon and Malloy, 2004 M.J. Khon and M.A. Malloy, Formation of monazite via prograde metamorphic reactions among common silicates: implications for age determinations, Geochim. Cosmochim. Acta 68 (2004), pp. 101-113.

Kusky and Li, 2003 T.M. Kusky and J.H. Li, Paleoproterozoic tectonic evolution of the North China craton, J. Asian Earth Sci. 22 (2003), pp. 23-40.

Li and Qian, 1991 J.H. Li and X.L. Qian, A study of Longquanguan shear zone in the northern part of the Taihang Mountain, Shanxi Geol. 6 (1991), pp. 17-29 (in Chinese).

Li and Qian, 1994 J.H. Li and X.L. Qian, Late Archean continental cratonization: evidence from Hengshan metamorphic terrain, North China Craton, Geological Evolution of the Granulitic Belt in the North Part of North China, Publishing House of Sismology, Beijing (1994) p. 234.

Li et al., 1997 J.H. Li, X.L. Qian and M.G. Zhai, Tectonic division of the North China granulite facies belt and its early Precambrian tectonic evolution, Sci. Geol. Sin. 32 (1997), pp. 254-266 (in Chinese with English abstract).

Li et al., 2000a J.H. Li, X.L. Qian, X.N. Huang and S.W. Liu, The tectonic framework of the basement of North China craton and its implication for the early Precambrian cratonization, Acta Petrol. Sin. 16 (2000), pp. 1-10.

Li et al., 2000b J.H. Li, A. Kröner, X.L. Qian and P. O'Brien, The tectonic evolution of an early Precambrian high-pressure granulite belt in the North China craton, Acta Geol. Sin. 74 (2000), pp. 246-256.

Li et al., 2004 J.H. Li, S.L. Niu and Z. Chen, Discovery of the deep thrusting structure in the Taihangshan area and its tectonic implications, Adv. Nat. Sci. 14 (2004), pp. 1118-1127.

Liu et al., 1985 D. Liu, Y. Page, R.W. Compston and W.J. Wu, U-Pb zircon geochronology of late Archean metamorphic rocks in the Taihangshan-Wutaishan area North China, Precambrian Res. 27 (1985), pp. 85-109.

Liu, 1996 S.W. Liu, $P-T$ path of the granulites in the Fuping Complex, Geol. J. Chin. Univ. 2 (1996), pp. 75-84 (in Chinese with English abstract).

Liu et al., 1997 S.W. Liu, A.J. Wang and X.F. Li, Metamorphic evolution of the late Archean Wutai collisional belt, Geol. J. Chin. Univ. 3 (1997), pp. 162-170.

Liu et al., 2002 S.W. Liu, J.H. Li, Y.M. Pan, J. Zhang and Q.G. Li, An Archean continental block in the Taihangshan and Hengshan regions: constraints from geochronology and geochemistry, Prog. Nat. Sci. 12 (2002), pp. 568-576. 
Liu et al., 2004 S.W. Liu, Y.M. Pan, Q.L. Xie, J. Zhang and Q.G. Li, Archean geodynamics in the Central Zone, North China craton: constraints from geochemistry of two contrasting series of granitoids in the Fuping and Wutai complexes, Precambrian Res. 130 (2004), pp. 229-249.

Liu et al., 2006 S.W. Liu, G.C. Zhao, S.A. Wilde, G. Shu, M. Sun, Q. Li, W. Tian and J. Zhang, Th-U-Pb monazite geochronology of the Luliang and Wutai complexes: constraints on the tectonothermal evolution of the Trans-North China orogen, Precambrian Res. 148 (2006), pp. 205-224.

Ma et al., 1987 X.Y. Ma, J. Bai, S.T. Suo, Q.Y. Lao and J.S. Zhang, The Precambrian Tectonic Framework and the Research Method in China, Geological Publishing House, Beijing (1987) (in Chinese with English abstract).

Ma and Wu, 1981 X.Y. Ma and Z.W. Wu, Early tectonic evolution of China, Precambrian Res. 14 (1981), pp. 185-202.

Marshak, 1999 S. Marshak, Deformation style way back when: thoughts on the contrasts between Archean/Paleoproterozoic and contemporary orogens, J. Struct. Geol. 21 (1999), pp. $1175-1182$.

Montel et al., 1996 J.M. Montel, S. Foret, M. Veschambre, C. Nicollet and A. Provost, Electron microprobe dating of monazite, Chem. Geol. 131 (1996), pp. 37-53.

O'brien et al., 2005 P.J. O'brien, N. Walte and J.H. Li, The petrology of two distinct Paleoproterozoic granulite types in the Hengshan Mts., North China Craton, and tectonic implications, J. Asian Earth Sci. 24 (2005), pp. 615-627.

Parrish, 1990 R.R. Parrish, U-Pb dating of monazite and its application to geological problems, Can. J. Earth Sci. 27 (1990), pp. 1431-1450.

Pei et al., 2001 L.T. Pei, M. Yang, G.X. Ma, T.P. Hao, Z.H. Han and J.L. Bin, The geological character of the Longquanguan ductile shear zone, Beijing Geol. 13 (2001), pp. 1-11 (in Chinese with English abstract).

Pommier et al., 2002 Pommier, A., Cocherie, A., Legendre, O., 2002. EPMA Dating User's Manual: Age Calculation from Electron Probe Microanalyser Measurements of $\mathrm{U}-\mathrm{Th}-\mathrm{Pb}$. BRGM, 9 pp.

Polat et al., 2005 A. Polat, T. Kusky, J.H. Li, B. Fryer, R. Kerrich and K. Patrick, Geochemistry of Neoarchean (ca. 2.55-2.50 Ga) volcanic and ophiolitic rocks in the Wutaishan greenstone belt, central orogenic belt, North China craton: implications for geodynamic setting and continental growth, Geol. Soc. Am. Bull. 117 (11/12) (2005), pp. 1387-1399.

Polat et al., 2006 A. Polat, C. Hersberg, C. Münker, R. Rodgers, T. Kusky, J.H. Li, B. Fryer and J. Delaney, Geochemical and petrological evidence for a suprasubduction zone origin of Neoarchean (ca. $2.5 \mathrm{Ga}$ ) peridotites, central orogenic belt, North China craton, Geol. Soc. Am. Bull. 118 (7/8) (2006), pp. 771-784. 
Rasmussen, 1996 B. Rasmussen, Early diagenetic REE-phosphates minerals (florencite, gorceixite, crandallite and xenotime) in marine sandstones: a major sink for oceanic phosphorus, Am. J. Sci. 296 (1996), pp. 601-632.

Simpson et al., 2000 R.L. Simpson, R.R. Parrish, M.P. Searle and D.J. Waters, Two episodes of monazite crystallisation during metamorphism and crustal melting in the Everest region of the Nepalese Himalaya, Geology 28 (2000), pp. 403-406.

Smith and Barreiro, 1990 H.A. Smith and B. Barreiro, Monazite U-Pb dating of staurolite grade metamorphism in pelitic schists, Contrib. Mineral. Petrol. 105 (1990), pp. 602-615.

Smith and Giletti, 1997 H.A. Smith and B.J. Giletti, Lead diffusion in monazite, Geochim. Cosmochim. Acta 61 (1997), pp. 1047-1055.

Spear and Pyle, 2002 F.S. Spear and J.M. Pyle, Apaptite, monazite, and xenotime in metamorphic rocks. In: M.J. Khon, J. Rakovan and J.M. Hugues, Editors, Phosphates: Geochemical, Geobiological and Materials Importance, Reviews in Mineralogy and Geochemistry vol.48, Mineralogical Society of America (2002), pp. 293-335.

Sun et al., 1992 M. Sun, R.L. Armstrong and R.J. Lambert, Petrochemistry and Sr, Pb, and $\mathrm{Nd}$ isotopic geochemistry of early Precambrian rocks, Wutaishan and Taihangshan areas, China, Precambrian Res. 56 (1992), pp. 1-31.

Sun et al., 2004 Z.L. Sun, J.R. Li, C.R. Liu, Y.S. Zhang, Y.H. Yang and W.S. Yan, Another view on the Longquanguan Ductile Shear Zone, Geol. Surv. Res. 27 (2004), pp. 92-100 (in Chinese with English abstract).

Suzuki et al., 1994 K. Suzuki, M. Adachi and I. Kajizuka, Electron microprobe observations of $\mathrm{Pb}$ diffusion in metamorphosed detrital monazites, Earth Planet Sci. Lett. 128 (1994), pp. 391-405.

Tian, 1991 Y.Q. Tian, Greenstone Belt Geology in Wutaishan-Hengshan and Au Metallization, Shanxi Science and Technology Press, Taiyuan (1991) pp. 35-46 (in Chinese).

Tian et al., 1996 Tian, Y.Q., Ma, Z.H., Yu, K.R., Liu, Z.H., Peng, Q.M., 1996. The early Precambrian geology of Wutai-Hengshan Mts., Shanxi, China. In: Field Trip Guide T315 30th International Geological Congress, Beijing, China. Geological Publishing House, Beijing, 52 pp.

P. Trap, M. Faure, W. Lin, N. Le Breton, O. Bruguier and P. Monié, Structural, metamorphic and geochronological works in the Hengshan-Wutaishan-Fuping massifs and correlation with the Lüliang massif: implication for the tectonic evolution of the Trans-North China Belt, IAGR Annual Convention \& International Symposium 2006 Hong-Kong, China (2006), pp. 55-56 (abstract).

Wang et al., 1991 R.M. Wang, Z.Z. Chen and F. Chen, Grey gneisses and high-pressure granulite enclaves in the Hengshan area and their geological implications, Acta. Petrol. Sin. 7 (1991), pp. 36-46 (in Chinese with English abstract). 
Wang et al., 1996 K.Y. Wang, J.L. Li, J. Hao, J.H. Li and S.P. Zhou, The Wutaishan mountain belt within the Shanxi province, Northern China: a record of late Archean collision tectonics, Precambrian Res. 78 (1996), pp. 95-103

Wang et al., 1997 K.Y. Wang, J. Hao, P. Cawood and S.A. Wilde, High-pressure metamorphism in kyanite-bearing schists from the original Jingangku Formation of the Wutaishan, Proceeding of the 30th IGC: Precambrian Geol. Metamorph. Petrol., vol. 17 (1997), pp. 213-220.

Wang et al., 2001 K.Y. Wang, Z. Wang, L. Yu, H. Fan, S.A. Wilde and P.A. Cawood, Evolution of Archaean greenstone belt in the Wutaishan region, North China: constraints from SHRIMP zircon U-Pb and other geochronological and isotope information. In: K.F. Cassidy, Editor, Proceedings of the 4th International Archaean Symposium 2001, Extended Abstracts Australian Geological Survey Organization, Geoscience Australia (2001), pp. 104-105 (Record 37).

Wang et al., 2004 Z. Wang, S.A. Wilde, K. Wang and L. Yu, A MORB-arc basalt-adakite association in the $2.5 \mathrm{GaWutai}$ greenstone belt: late Archean magmatism and crustal growth in the North China Craton, Precambrian Res. 131 (2004), pp. 323-343.

Wilde et al., 1997 S.A. Wilde, P. Cawood, K.Y. Wang and A. Nemchin, The relationship and timing of granitoid evolution with respect to felsic volcanism in the Wutai Complex, North China Craton, Proceedings of the 30th International Geological Congress, Beijing, Precambrian Geol. Metamorph. Petrol. 17 (1997), pp. 75-88.

Wilde et al., 1998 S.A. Wilde, P.A. Cawood, K.Y. Wang and A. Nemchin, SHRIMP U-Pb zircon dating of granites and gneisses in the Taihangshan-Wutaishan area: implications for the timing of crustal growth in the North China craton, Chinese Sci. Bull. 43 (1998), pp. 144 145.

Wilde et al., 2002 S.A. Wilde, G.C. Zhao and M. Sun, Development of the North China Craton during the late Archean and its final amalgamation at $1.8 \mathrm{Ga}$; some speculations on its position within a global Paleoprterozoic Supercontinent, Gondwana Res. 5 (2002), pp. 85-94.

Wilde and Wang, 1995 Wilde, S.A., Wang, K.Y., 1995. The nature and age of felsic volcanism within the late Archean Wutai complex, Sino-Korean Craton, China. Precambrian '95 tectonics and Metallogeny of the Early/Mid Precambrian Orogenic Belts, Montreal, Canada, 61.

Wilde et al., 2004a S.A. Wilde, P.A. Cawood, K.Y. Wang, A. Nemchin and G.C. Zhao, Determining Precambrian crustal evolution in China: a case study from Wutaishan, Shanxi Province, demonstrating the application of precise SHRIMP U-Pb geochronology. In: J. Malpas, C.J.N. Fletcher, J.R. Ali and J.C. Aitchison, Editors, Aspects of the Tectonic Evolution of China vol. 226, Geological Society of London (2004), pp. 5-25 (special publication).

Wilde et al., 2004b S.A. Wilde, G.C. Zhao, K.Y. Wang and M. Sun, First SHRIMP zircon U$\mathrm{Pb}$ ages for the Hutuo Group in Wutaishan: further evidence for amalgamation of North China Craton, Chinese Sci. Bull. 49 (2004), pp. 83-90. 
Wilde et al., 2005 S.A. Wilde, P.A. Cawood, K.Y. Wang and A. Nemchin, Granitoid evolution in the late Archean Wutai Complex, North China Craton, J. Asian Earth Sci. 24 (2005), pp. 597-613.

Wu et al., $1986 \mathrm{~J}$. Wu, D. Liu and L. Jin, The zircon U-Pb age of metabasic volcanic lavas from the Hutuo Group in the Wutai mountain area, Shanxi Province, Geol. Rev. 32 (1986), pp. 178-184 (in Chinese).

Wu and Zhong, 1998 C.H. Wu and C.T. Zhong, The paleaoproterozoic SW-NE collision model for the central North China Craton, Prog. Precambrian Res. 21 (1998), pp. 28-50 (in Chinese).

Wu et al., 2005 F.Y. Wu, G.C. Zhao, S.A. Wilde and D. Sun, Nd isotopic constraints on crustal formation in the North China Craton, J. Asian Earth Sci. 24 (2005), pp. 523-545.

Xu et al., 1995 R.H. Xu, M. Zhu, F.K. Chen and J.H. Guo, A geochronological study of the Longquanguan ductile shear zone, Quaternary Sci. 4 (1995), pp. 332-342.

Yan et al., 1996 Y.H. Yan, J.H. Li and W.J. Liu, Huai'an massif and Hengshan massif. In: M.G. Zhai, Editor, Granulites and Lower Continental Crust in North China Archean Craton, Seismological Press, Beijing (1996), pp. 55-131.

Zhai et al., 2000 M.G. Zhai, A.G. Bian and T.P. Zhao, The amalgamation of the supercontinent of North China Craton at the end of Neo-Archaean and its breakup during late Palaeoproterozoic and Mesoproterozoic, Sci. Chin. Ser. D 43 (2000), pp. 219-232.

Zhang et al., 2006a J. Zhang, G.C. Zhao, M. Sun, S.A. Wilde, L. Sanzhong and S. Li, Highpressure mafic granulites in the Trans-North China orogen: tectonic significance and age, Gondwana Res. 9 (2006), pp. 349-362.

Zhang et al., 2006b Zhang, J., Zhao, G.C., Li, S., Sun, M., Liu, S., 2006b. Structural geology of the Fuping complex: constraints on the tectonic evolution of the Trans-North China Orogen. In: AGU Western Pacific Geophysics Meeting, Abstract No. TI2B-03.

Zhao et al., 1999a G.C. Zhao, S.A. Wilde, P.A. Cawood and L.Z. Li, Tectonothermal history of the basement rocks in the western zone of the North China Craton and its tectonic implications, Tectonophysics 310 (1999), pp. 37-53.

Zhao et al., 1999b G.C. Zhao, P.A. Cawood and L.Z. Lu, Petrology and $P-T$ history of the Wutai amphibolites: implications for tectonic evolution of the Wutai complex, China, Precambrian Res. 93 (1999), pp. 181-199.

Zhao et al., 2000a G.C. Zhao, P.A. Cawood, S.A. Wilde and L.Z. Lu, Metamorphism of basement rocks in the Central Zone of the North China Craton: implications for Paleoproterozoic tectonic evolution, Precambrian Res. 103 (2000), pp. 55-88.

Zhao et al., 2000b G.C. Zhao, S.A. Wilde, P.A. Cawood and L.Z. Lu, Petrology and $P-T$ path of the Fuping mafic granulites: implications for tectonic evolution of the central zone of the North China Craton, J. Metamorph. Geol. 18 (2000), pp. 375-391. 
Zhao et al., 2001a G.C. Zhao, S.A. Wilde, P.A. Cawood and M. Sun, Archean blocks and their boundaries in the North China Craton: lithological, geochemical, structural and $P-T$ path constraints and tectonic evolution, Precambrian Res. 107 (2001), pp. 45-73.

Zhao et al., 2001b G.C. Zhao, P.A. Cawood, S.A. Wilde and L.Z. Lu, High-pressure granulites (retrograded eclogites) from the Hengshan Complex North China Craton: petrology and tectonic implications, J. Petrol. 42 (2001), pp. 1141-1170.

Zhao et al., 2002 G.C. Zhao, S.A. Wilde, P.A. Cawood and M. Sun, SHRIMP U-Pb zircon ages of the Fuping Complex: implications for late Archean to Paleoproterozoic accretion and assembly of the North China Craton, Am. J. Sci. 302 (2002), pp. 191-226.

Zhao et al., 2004 G.C. Zhao, M. Sun, S.A. Wilde and J.H. Guo, Late Archean to Palaeoproterozoic evolution of the trans-North China Orogen: insights from synthesis of existing data from the Hengshan-Wutai-Fuping belt. In: J. Malpas, C.J.N. Fletcher, J.R. Ali and J.C. Aitchison, Editors, Aspects of the Tectonic Evolution of China vol. 226, Geological Society of London (2004), pp. 27-55 (special publication).

Zhao et al., 2005 G.C. Zhao, M. Sun, S.A. Wilde and S. Li, Late Archean to Paleoproterozoic evolution of the North China Craton: key issues revisited, Precambrian Res. 136 (2005), pp. 177-202.

Zhao et al., 2006 L. Zhao, J.J. Zhang and S.W. Liu, Syn-deformational granites of the Longquanguan ductile shear zone and their monazite electronic microprobe dating, Acta Petrol. Mineral. 25 (2006), pp. 210-218.

Zhu et al., 1997 X.K. Zhu, R.K. O’Nions, N.S. Belshaw and A.J. Gibb, Significance of in situ SIMS chronometry of zoned monazite from the Lewisian granulites, northwest Scotland, Chem. Geol. 135 (1997), pp. 35-53. 


\section{Figures}

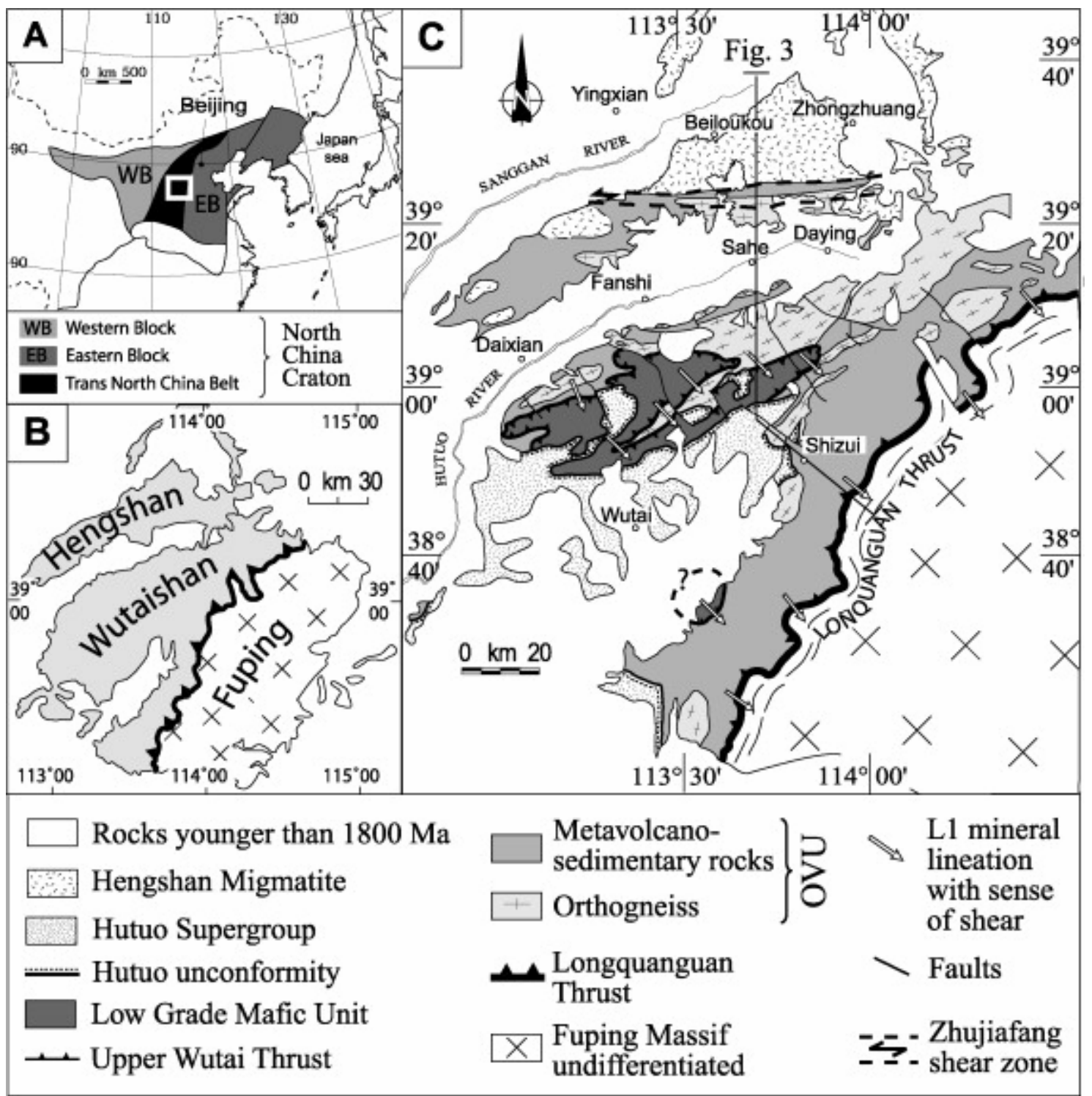

Fig. 1. (A) Location of the Trans-North-China Belt (TNCB), Western and Eastern Blocks (WB and EB) within the North China Craton. (B) Geographic relations between the Hengshan-Wutaishan domain and the Fuping massif. (C) Structural map of the HengshanWutaishan domain. The crustal-scale cross section is shown in Fig. 3. 


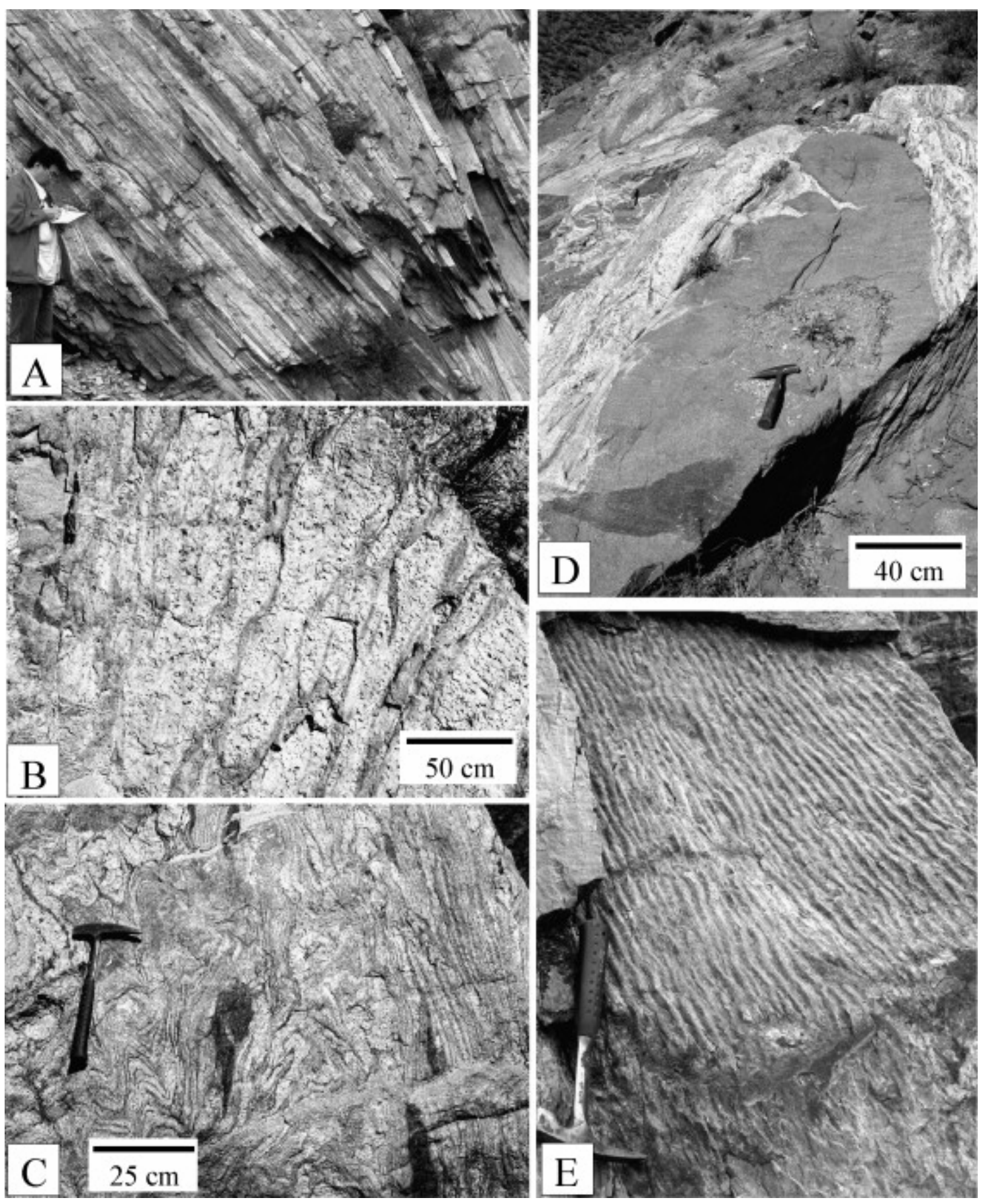

Fig. 2. Examples of rock-types in the Hengshan-Wutaishan domain. (A) OVU volcanic rocks here defined by centimeter-scale alternations of light-colored quartzo-feldspathic gneiss and amphibolite-bearing gneiss (N39 $\left.10.567^{\prime} / \mathrm{E} 112^{\circ} 50.321^{\prime}\right)$. (B) LGMU metabasalts with pillows flattened parallel to the $\mathrm{S} 1$ foliation $\left(\mathrm{N} 39^{\circ} 01.617^{\prime} / \mathrm{E} 113^{\circ} 19.903^{\prime}\right)$. (C) Migmatite characterized by folded leucosomes and restite (N39 $\left.26.810^{\prime} / \mathrm{E} 113^{\circ} 23.882^{\prime}\right)$. (D) Elliptical block of granulitic restite in the migmatite, note the migmatitic melt coming inside the block $\left(\mathrm{N} 39^{\circ} 25.575^{\prime} / \mathrm{E} 113^{\circ} 52.289^{\prime}\right)$. (E) Hutuo Supergroup unmetamorphozed sandstone with well preserved ripple marks $\left(\mathrm{N} 38^{\circ} 44.053^{\prime} / \mathrm{E} 112^{\circ} 52.623^{\prime}\right)$. 


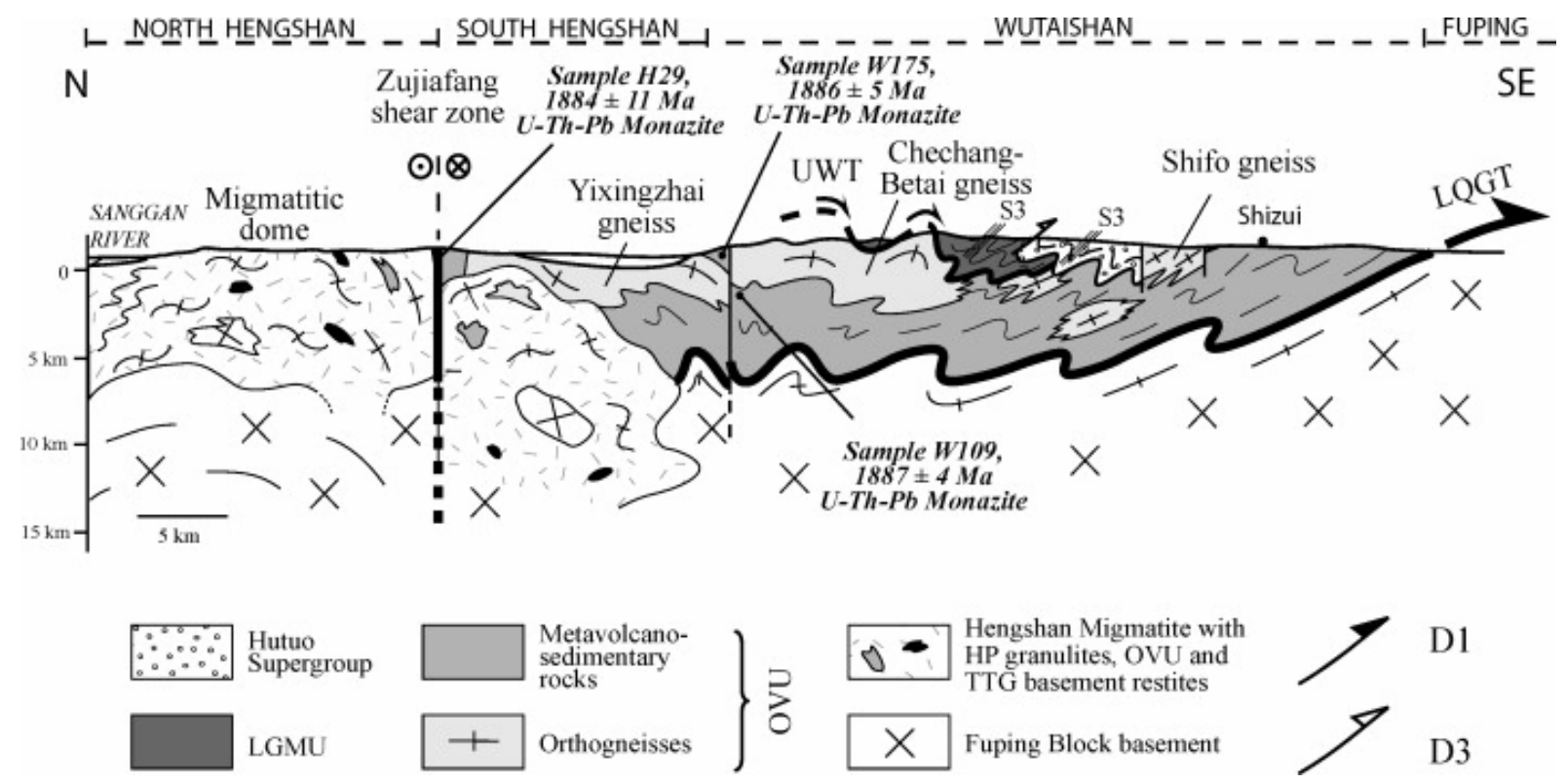

Fig. 3. Kilometer-scale cross-section through Hengshan and Wutaishan massifs, from the Sanggan River to the Longquanguan Thrust (LQGT). See location in Fig. 1. UWT: Upper Wutai Thrust. 


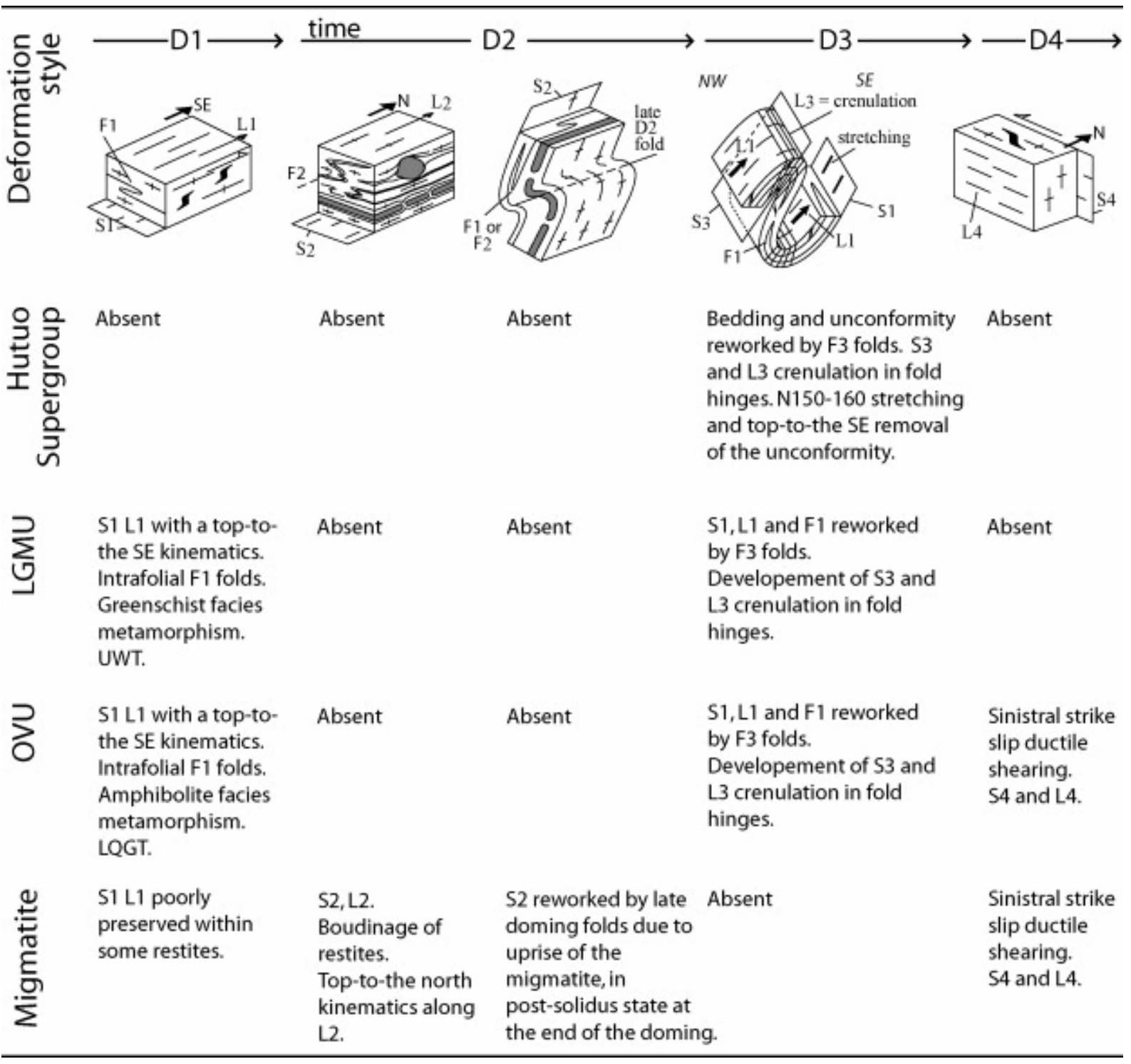

Fig. 4. Deformation events recognized in Migmatite, OVU, LGMU and Hutuo Supergroup related to polyphase deformation of the Hengshan-Wutaishan domain. 


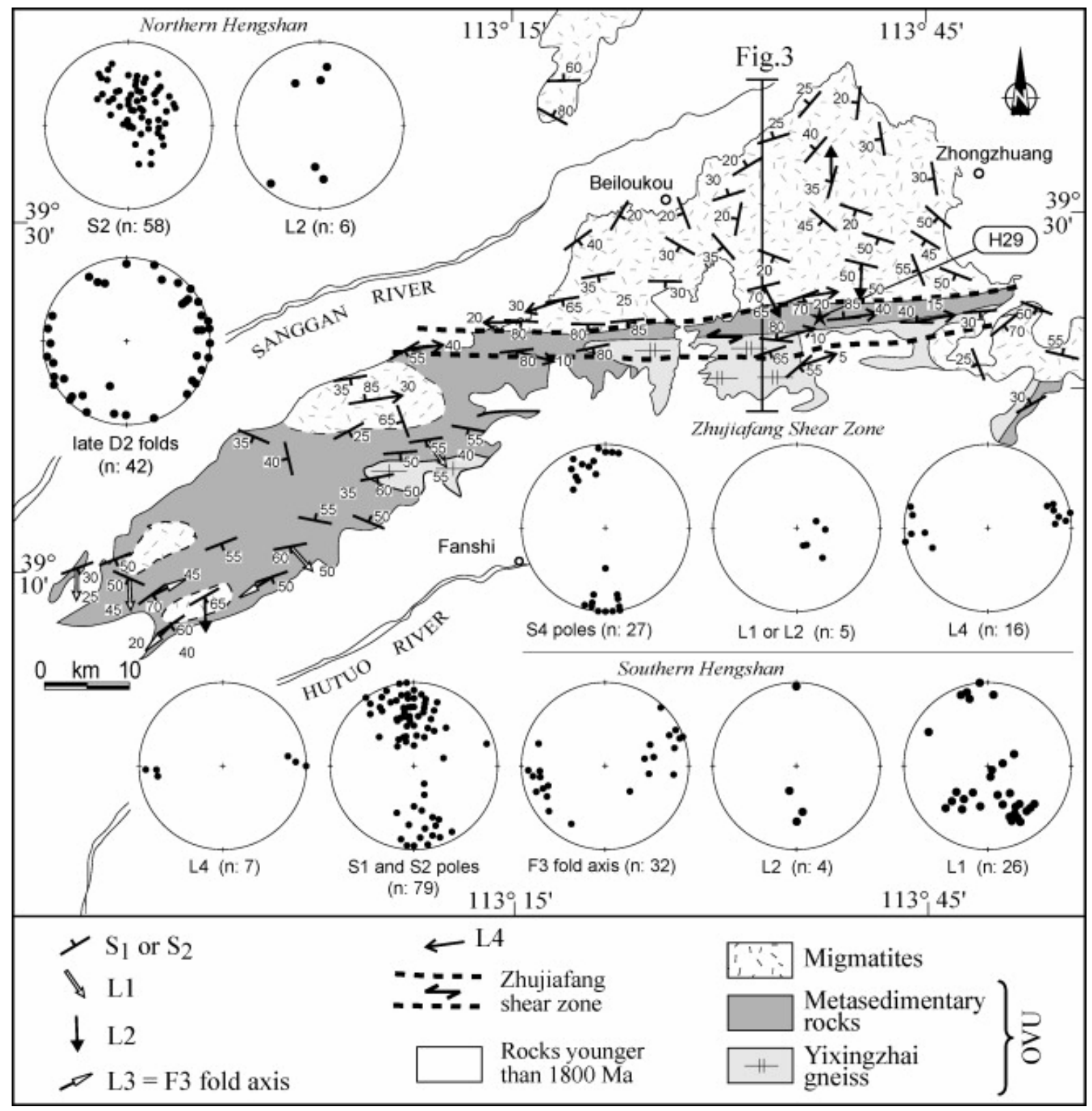

Fig. 5. Structural map of the Hengshan massif. Foliation poles and linear elements of the North Hengshan, South Hengshan and Zhujiafang Shear Zone are reported in equiareal, lower hemisphere, Schmidt nets. The location of the dated H29 sample (see Section 4) in the Zhujiafang shear zone is indicated by a black star. 


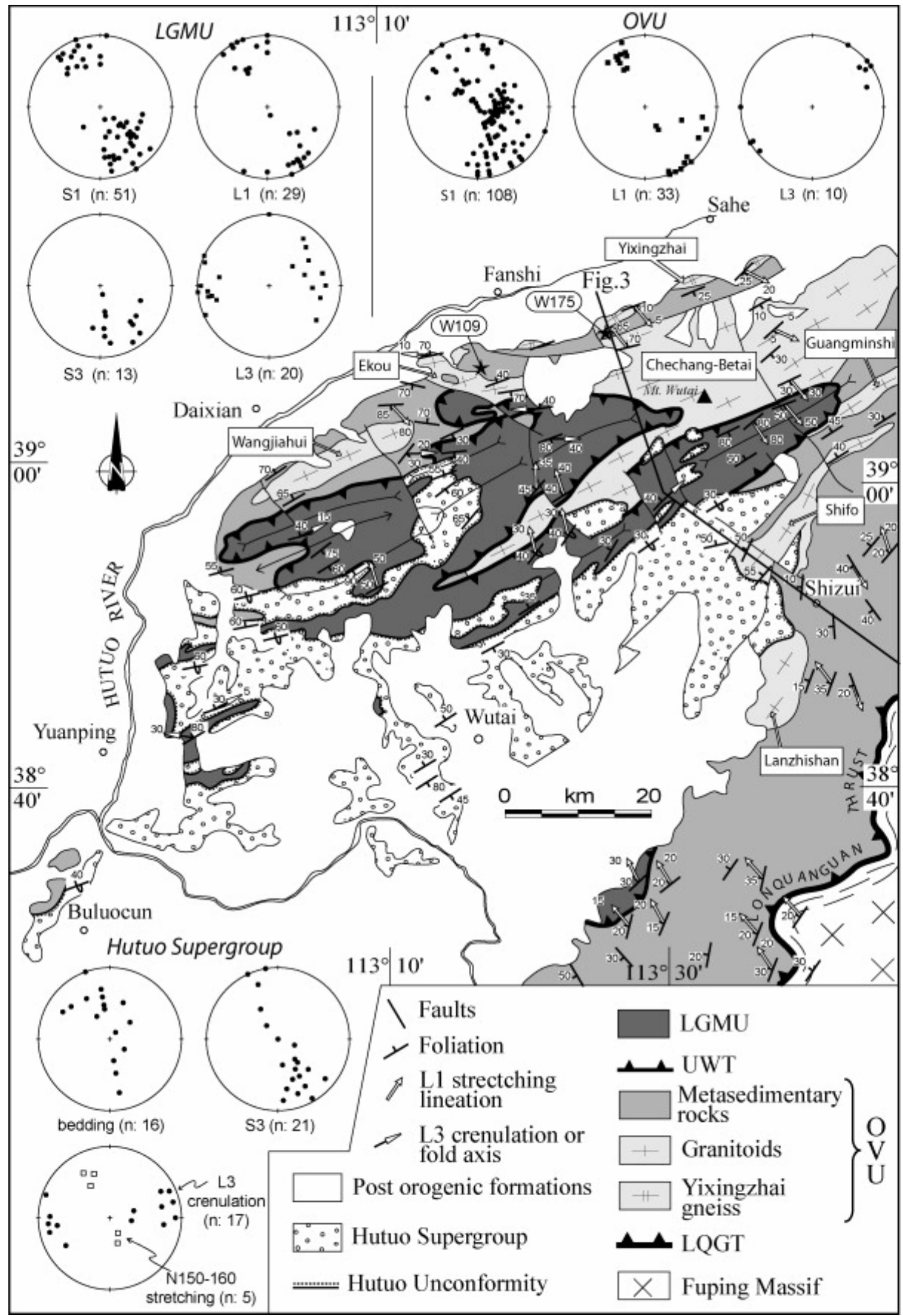

Fig. 6. Structural map of the Wutaishan massif. Structural linear elements are reported in equiareal, lower hemisphere, Schmidt nets. Note that the Hutuo Supergroup unconformably overlies both the OVU and the LGMU but the sedimentary contact is frequently reworked. The black stars mark the location of dated samples W109 and W175 (see Section 4). LGMU: 
Lower Grade Mafic Unit; UWT: Upper Wutai Thrust; OVU: Orthogneiss and Volcanites Unit; LQGT: Longquanguan Thrust.

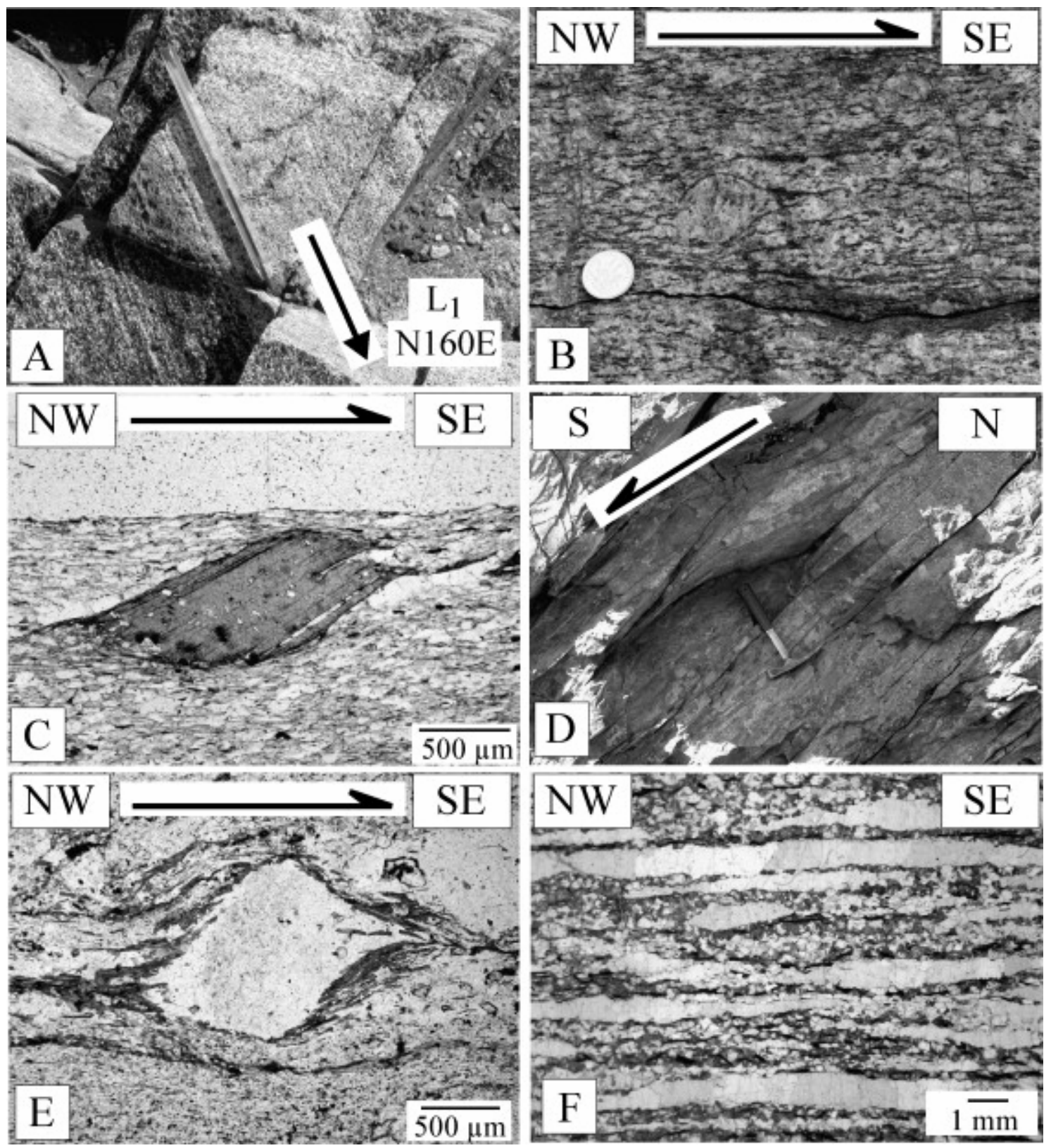

Fig. 7. (A) Example of the NW-SE trending mineral lineation (L1) here defined by oriented amphibole and biotite aggregates, the foliation is flat lying (Yixingzhai gneiss in Hengshan massif, N39 $20.024^{\prime} / \mathrm{E} 113^{\circ} 05.856^{\prime}$ ). (B) Sigma-type porphyroclast in an augen gneiss from the OVU along the Longquanguan Thrust, the foliation is flat lying and the lineation trends $\mathrm{N} 160^{\circ}\left(\mathrm{N} 38^{\circ} 54.879^{\prime} / \mathrm{E}^{1} 13^{\circ} 47.600^{\prime}\right)$. (C) Biotite fish in a metapelite of the OVU showing a top-to-the SE kinematics (east of Daixian, N39 $04.648^{\prime} / \mathrm{E} 113^{\circ} 07.487^{\prime}$ ). (D) Top-to-the $\mathrm{S}$ shear criteria in a chlorite schist from the LGMU (N39 $\left.04.820^{\prime} / \mathrm{E} 113^{\circ} 39.167^{\prime}\right)$. (E) Top-to-the SE kinematics marked by quartz + chlorite asymmetric pressure shadows around feldspar porphyroclast, in a volcanite from the LGMU (N39 $\left.01.827^{\prime} / \mathrm{E} 113^{\circ} 20.357^{\prime}\right)$. (F) Ultramylonitic fabric characterized by quartz ribbons, in a felsic gneiss from the OVU (Longquanguan Thrust, N39 $12.488^{\prime} / \mathrm{E} 114^{\circ} 18.044^{\prime}$ ). 

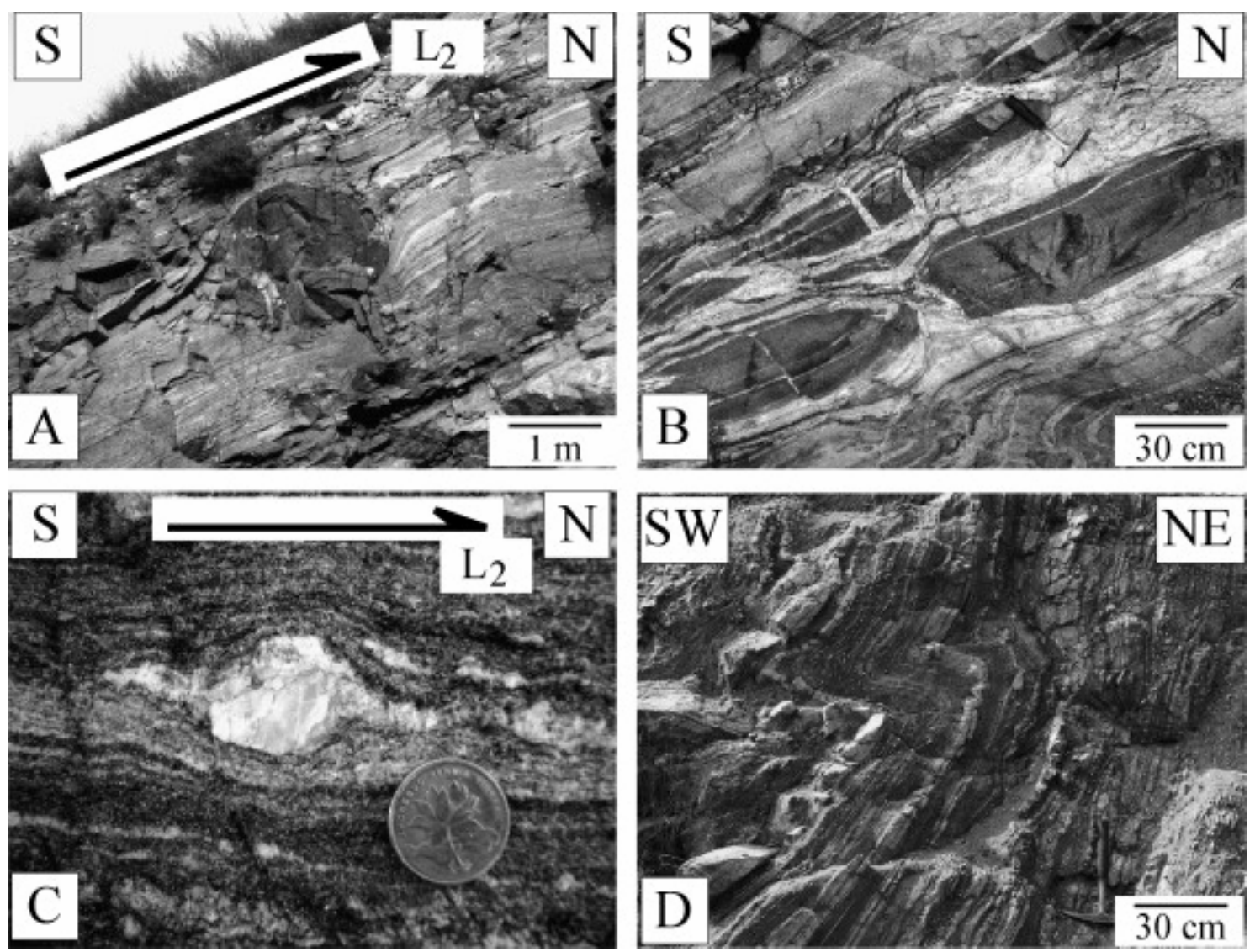

Fig. 8. Field evidences for D2 event in North Hengshan migmatite. (A) Asymmetric amphibolite restite enclosed within the gneissic migmatite, the pressure shadows define a topto-the $\mathrm{N}$ shearing $\left(\mathrm{N} 39^{\circ} 30.048^{\prime} / \mathrm{E} 113^{\circ} 26.852^{\prime}\right)$. (B) Boudins of amphibolite in the gneissic migmatite $\left(\mathrm{N} 39^{\circ} 30.078^{\prime} / \mathrm{E} 113^{\circ} 26.932^{\prime}\right)$. (C) Sigma-type porphyroclast showing a top-to-the N shear criteria in the gneissic migmatite (N39 $\left.27.451^{\prime} / \mathrm{E} 113^{\circ} 20.584^{\prime}\right)$. (D) S2 migmatite foliation reworked by late D2 folds overturned to the $\mathrm{SW}\left(\mathrm{N} 39^{\circ} 30.003^{\prime} / \mathrm{E} 113^{\circ} 36.566^{\prime}\right)$. 

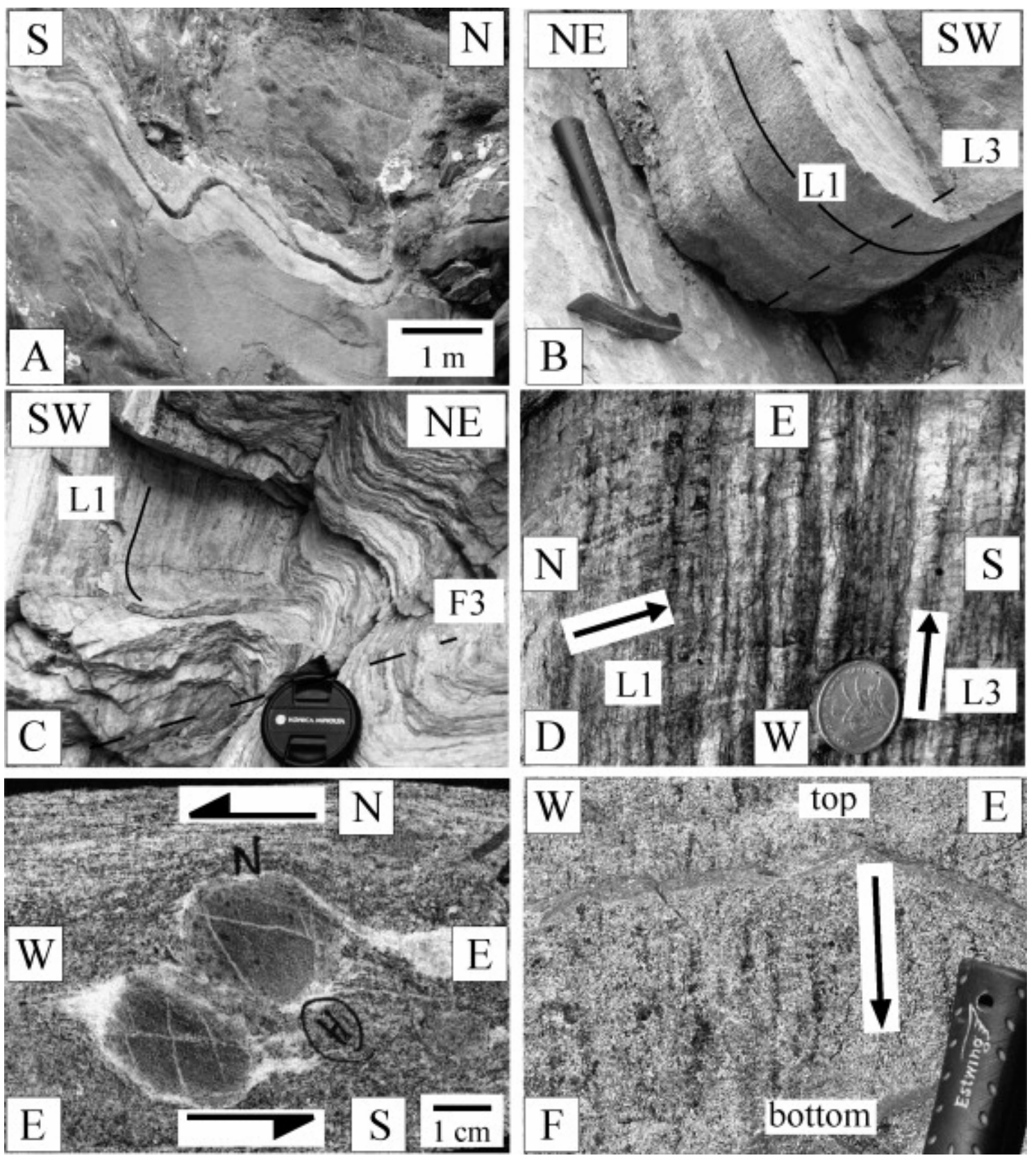

Fig. 9. Field evidences for polyphase deformation in the Hengshan-Wutaishan area. (A) S1 foliation deformed by upright F3 folds in the OVU (southwest of Ekou, $\mathrm{N} 39^{\circ} 05.201^{\prime} / \mathrm{E} 113^{\circ} 07.431^{\prime}$ ). (B and C) S1 foliation and L1 lineation reworked by F3 folds in the LGMU (near Yuli village, N38 $43.780^{\prime} / \mathrm{E} 112^{\circ} 52.684^{\prime}$ ). Note the crenulation that develops in the $\mathrm{F} 3$ fold hinges (photo C). (D) E-W trending S3 fold with L3 crenulation reworking the $\mathrm{N}-\mathrm{S}$ trending L1 lineation (same outcrop). (E) Asymmetric quartz pressure shadows around garnet porphyroblasts showing a sinistral sense of shear within the strike-slip Zhujiafang shear zone (near Zhujiafang village, N39 $23.743^{\prime} / \mathrm{E} 113^{\circ} 35.831^{\prime}$ ). (F) Down dip lineation in amphibolite restite in the migmatite, close to the northern boundary of the ZSZ indicating a vertical movement older than the strike-slip shearing (near Zhujiafang village, $\left.\mathrm{N} 39^{\circ} 24.478^{\prime} / \mathrm{E} 113^{\circ} 35.835^{\prime}\right)$. 

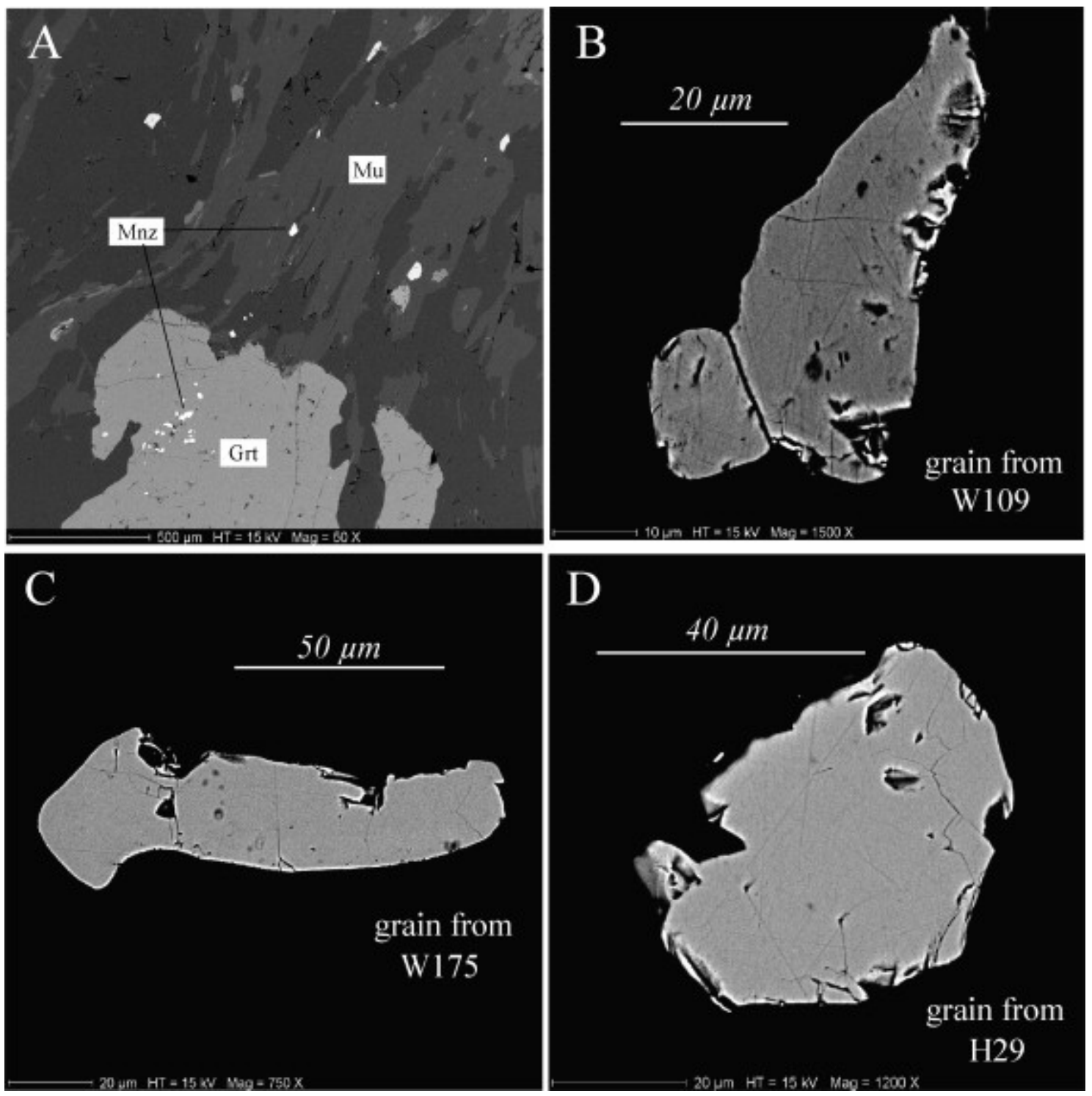

Fig. 10. (A) BSE image showing location of monazite within garnet rim and muscovite of the matrix, in the sample W109. (B-D) BSE images of representative monazite grains without any zoning, from samples W109, W175 and H29, respectively. 

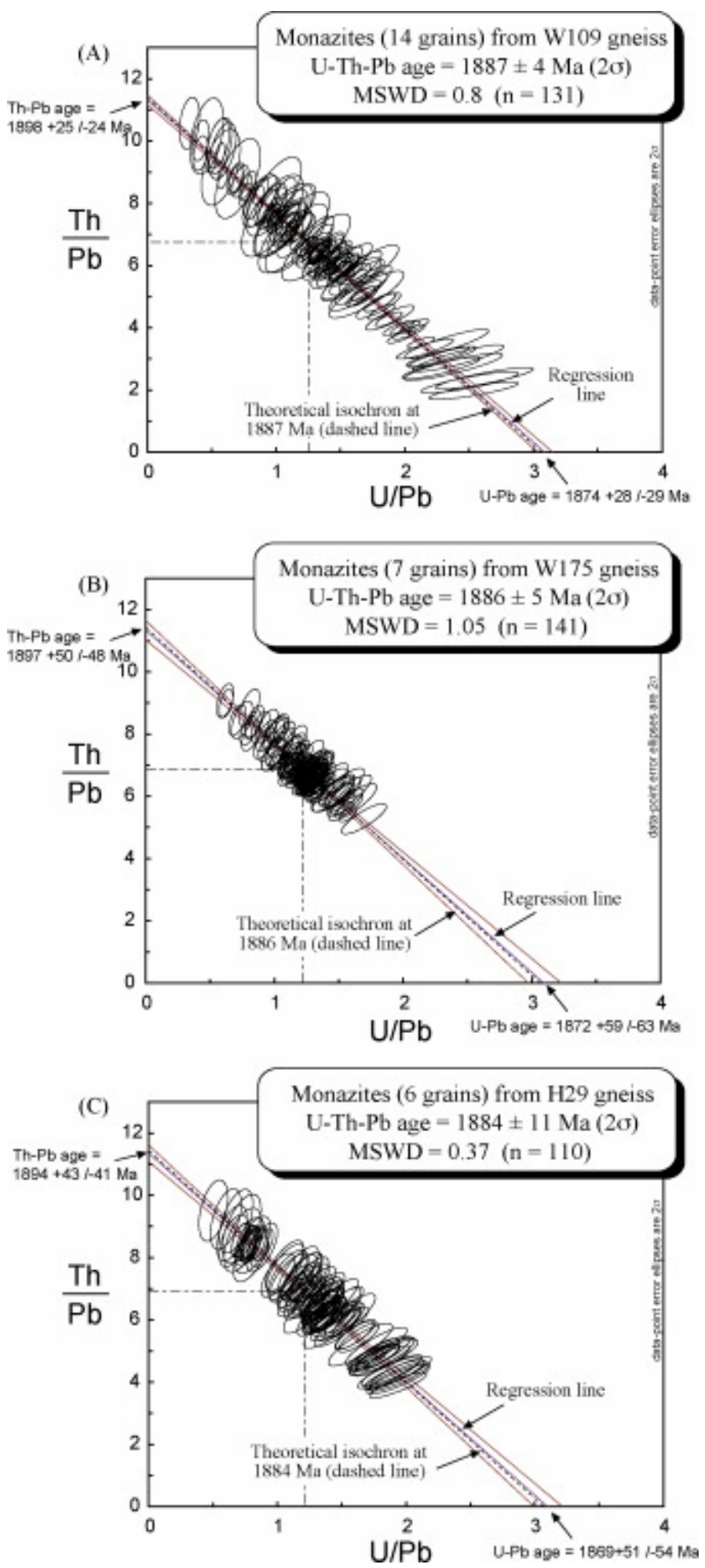

Fig. 11. Isochron diagrams according to Cocherie and Albarede (2001) for monazites from samples W109, W175 and H29. The mean age is calculated at the population centroid (dashed and dotted lines) where the error is the smallest. For all samples the regression line is close to the theoretical isochron at the calculated age (dashed line). See text for explanations. 



\section{Tables}

Table 1. : Summary of electron microprobe data for analyzed monazites showing the range of U, Th and Pb for sample W109, W175 and H29

\begin{tabular}{|c|c|c|c|c|c|c|}
\hline & $\begin{array}{l}\mathrm{U}(\mathbf{p p m}) \pm \sigma \\
\text { S.D. }\end{array}$ & $\begin{array}{l}\text { Th }(\mathbf{p p m}) \pm \sigma \\
\text { S.D. }\end{array}$ & $\begin{array}{l}\text { Pb }(\mathbf{p p m}) \pm \sigma \\
\text { S.D. }\end{array}$ & $\begin{array}{l}\text { Th/U } \pm \sigma \\
\text { S.D. }\end{array}$ & $\begin{array}{l}\text { Isochron } \\
\text { age } \pm 2 \sigma \mathrm{Ma}\end{array}$ & $\begin{array}{l}\text { Nb. of } \\
\text { data }\end{array}$ \\
\hline $\begin{array}{l}\text { Sample W109 (14 grains) } \\
\text { N39 }^{\circ} 06.679^{\prime} / \text { E1 } 13^{\circ} 14.334^{\prime}\end{array}$ & $3907 \pm 1776$ & $20305 \pm 11230$ & $3047 \pm 1276$ & $6.4 \pm 5.1$ & $1887 \pm 4$ & 131 \\
\hline 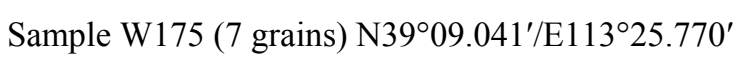 & $4231 \pm 992$ & $23935 \pm 4882$ & $3471 \pm 651$ & $5.9 \pm 1.9$ & $1886 \pm 5$ & 141 \\
\hline 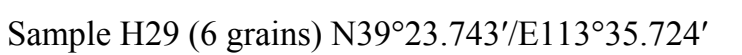 & $2735 \pm 722$ & $14829 \pm 5753$ & $2186 \pm 521$ & $6.1 \pm 3.4$ & $1884 \pm 11$ & 110 \\
\hline
\end{tabular}

